2015

\title{
Identification and quantification of diffuse fresh submarine groundwater discharge via airborne thermal infrared remote sensing
}

Joseph T. Tamborski

SUNY Stony Brook

A Deanne Rogers

SUNY Stony Brook

Henry J. Bokuniewicz

SUNY Stony Brook

J Kirk Cochran

SUNY Stony Brook

Caitlin R. Young

SUNY Stony Brook

Follow this and additional works at: https://commons.library.stonybrook.edu/geo-articles

Part of the Geochemistry Commons, Geology Commons, Geomorphology Commons, and the Geophysics and Seismology Commons

\section{Recommended Citation}

Tamborski, J., A. D. Rogers, H. Bokuniewicz, K. Cochran, and C. Young, Identification and quantification of diffuse fresh submarine groundwater discharge via airborne thermal infrared remote sensing, Remote Sensing of Environment, http://dx.doi.org/10.1016/ j.rse.2015.10.010, 2015. 


\title{
Identification and quantification of diffuse fresh submarine groundwater discharge via airborne thermal infrared remote sensing
}

\author{
Joseph J. Tamborski a,*, A. Deanne Rogers ${ }^{a}$, Henry J. Bokuniewicz ${ }^{\text {b }}$, J. Kirk Cochran ${ }^{\text {b }}$, Caitlin R. Young a,c \\ a Department of Geosciences, Stony Brook University, Stony Brook, NY 11794, USA \\ b School of Marine E Atmospheric Sciences, Stony Brook University, Stony Brook, NY 11794, USA \\ c Department of Geological Sciences, University of Florida, Gainesville, FL 32611, USA
}

\section{A R T I C L E I N F O}

\section{Article history:}

Received 2 June 2015

Received in revised form 7 October 2015

Accepted 21 October 2015

Available online $\mathrm{xxxx}$

\section{Keywords:}

Thermal infrared remote sensing

Submarine groundwater discharge

Fresh fraction

Radon

Radium

\begin{abstract}
A B S T R A C T
Airborne thermal infrared (TIR) overflights were combined with shoreline radionuclide surveys to investigate submarine groundwater discharge (SGD) along the north shore of Long Island, NY between June 2013 and September 2014. Regression equations developed for three distinct geomorphological environments suggest a positive linear relationship between the rate of diffuse SGD and the spatial extent of the observed coastal TIR anomalies; such a relationship provides quantitative evidence of the ability to use TIR remote sensing as a tool to remotely identify and measure SGD. Landsat TIR scenes were unable to resolve any of the 18 TIR anomalies identified during the various airborne overflights. Two locations were studied in greater detail via ${ }^{222} \mathrm{Rn}$ time series and manual seepage meters in order to understand why specific shoreline segments did not exhibit a TIR anomaly. SGD at the first site, located within a large, diffuse TIR anomaly, was composed of a mixture of fresh groundwater and circulated seawater with elevated levels of nitrate. In contrast, SGD at the second site, where no coastal TIR anomaly was observed, was composed of circulated seawater with negligible nitrate. Despite the compositional differences in seepage, both sites were similar in discharge magnitude, with average time series ${ }^{222} \mathrm{Rn}$ derived SGD rates equal to 18 and $8 \mathrm{~cm} \mathrm{~d}^{-1}$ for the TIR site and non-TIR site, respectively. Results suggest that TIR remote sensing has the ability to identify locations of a mixture between diffuse fresh and circulated seawater SGD. If TIR anomalies can be demonstrated to represent a mixture between fresh and circulated seawater SGD, then the cumulative area of the TIR anomalies may be used to estimate the fresh fraction of SGD relative to the cumulative area of the seepage face, and thus allows for improved SGD derived nutrient flux calculations on a regional scale.
\end{abstract}

(C) 2015 Elsevier Inc. All rights reserved.

\section{Introduction}

Submarine groundwater discharge (SGD) is defined as the net flow of terrestrial, meteorically derived freshwater and circulated seawater that discharges from a coastal aquifer to the sea (Moore, 1999). SGD may rival riverine inputs in terms of both water and chemical fluxes (Kwon et al., 2014; Slomp \& Van Cappellen, 2004) and is thus an important component of the hydrologic cycle. SGD has been shown to be an important driver of nutrient (particularly $\mathrm{NO}_{3}^{-}$) (Slomp \& Van Cappellen, 2004), metal (Beck et al., 2007; Knee \& Paytan, 2011), and carbon (Cyronak, Santos, Erler, Maher, \& Eyre, 2014; Santos et al., 2015 ) inputs to the coastal ocean. Excess nutrient loading derived from SGD has been linked to the onset of harmful algal blooms, as for example, in eastern Long Island, NY (Gobler \& Sanudo-Wilhelmy, 2001; Laroche et al., 1997) and dinoflagellate red-tide blooms in the southern sea of Korea (Lee, Kim, Lim, \& Hwang, 2010). Chemical fluxes sourced

\footnotetext{
* Corresponding author at: 345 Earth \& Space Sciences Building, Department of Geosciences, Stony Brook University, Stony Brook, NY 11794-21000, USA.

E-mail address: joseph.tamborski@stonybrook.edu (J.J. Tamborski).
}

from SGD have significant environmental repercussions and therefore need to be extensively characterized in order to aid in coastal remediation efforts.

The terrestrial hydraulic gradient is the primary mechanism for supplying fresh groundwater to the coast (Burnett et al., 2006; Santos, Eyre, \& Huettel, 2012; Taniguchi, Burnett, Cable, \& Turner, 2002) and this is the main source of new nutrients to the coastal ocean (Slomp \& Van Cappellen, 2004). SGD, including circulated seawater, is modulated by tidal pumping (Robinson, Gibbes, \& Li, 2006; Robinson, Li, \& Prommer, 2007), wave set-up (Xin, Robinson, Li, Barry, \& Bakhtyar, 2010), seasonal changes in water table height (Gonneea, Mulligan, \& Charette, 2013; Michael, Mulligan, \& Harvey, 2005), water level differences across barrier beaches (Bokuniewicz \& Pavlik, 1990; Rapaglia et al., 2010), density driven circulation (Robinson et al., 2007) and bioirrigation (Martin, Cable, Jaeger, Hartl, \& Smith, 2006). The fresh fraction of SGD widely varies among regions. On Long Island, NY alone, estimates range from less than 1\% (Garcia-Orellana et al., 2014) to upwards of 23\% (Young, 2013).

SGD is spatially and temporally variable, occurring as both pointsource plume discharge and as nonpoint-source, diffuse seepage. In typical unconfined coastal aquifers, SGD is concentrated near the coastline 
and decreases offshore (Bokuniewicz, 1980; Burnett et al., 2006), but may also occur as sporadic, heterogeneous flow offshore and as true submarine springs (Valle-Levinson, Marino-Tapia, Enriquez, \& Waterhouse, 2011). Hydraulic gradient, sediment porosity and aquifer type control SGD rates, with karstic (Mejias et al., 2012) and fractured bedrock aquifers (Bokuniewicz et al., 2008) typically experiencing higher, concentrated seepage rates compared to unconsolidated sandy aquifers, through which SGD is more diffuse.

Thermal infrared (TIR) remote sensing can resolve the spatial variation of groundwater discharge along a shoreline. Fresher, more buoyant SGD will rise above ambient saline surface-waters (Banks, Paylor, \& Hughes, 1996). For instance, fresh groundwater tends to exist at the average annual groundwater temperature (Anderson, 2005) and therefore has a distinct thermal signature from that of surface-waters. Detection of SGD via TIR remote sensing is possible in any environment where there is significant thermal contrast between the discharging pore fluid and the receiving surface-water body (Kelly, Glenn, \& Lucey, 2013). In northern latitudes, SGD will be cooler than surface-waters during summer months and warmer than the receiving surfacewaters during winter months (Pluhowski, 1972). The detection of SGD is greatest during times of highest thermal contrast under calm conditions and at low tide when SGD is expected to be greatest (Portnoy, Nowicki, Roman, \& Urish, 1998). Pluhowski (1972) pioneered the use of TIR remote sensing on Long Island, NY, where coastal TIR anomalies were associated with groundwater discharge, sewage outfall, stream morphology, and circulation patterns.

Airborne TIR remote sensing (Banks et al., 1996; Danielescu, MacQuarrie, \& Faux, 2009; Duarte, Hemond, Frankel, \& Frankel, 2006; Johnson, Glenn, Burnett, Peterson, \& Lucey, 2008; Kelly et al., 2013; Mejias et al., 2012; Mulligan \& Charette, 2006; Roseen, 2002) is a method used for detecting areas of potential groundwater discharge. At the appropriate scale, satellite TIR remote sensing is an effective tool for identifying areas of SGD for field investigation (Becker, 2006; Kageyama, Shibata, \& Nishida, 2012; Mallast et al., 2013; Sass, Creed, Riddell, \& Bayley, 2013; Tcherepanov, Zlotnik, \& Henebry, 2005). For example, time-series Landsat TIR data and coast$\mathrm{al}^{222} \mathrm{Rn}$ surveys have been used to identify over 30 new sources of SGD along the fractured bedrock coast of Ireland (Wilson \& Rocha, 2012). Space-borne synthetic aperture radar has been successfully used to identify SGD over large tidal flat regions (Kim, Moon, Kim, Park, \& Lee, 2011). Satellite data can also detect terrestrial groundwater discharge zones, as Sass et al. (2013) demonstrate with Landsat TIR data from Alberta, Canada. Airborne TIR remote sensing, however, is capable of resolving SGD at a much higher spatial resolution than satellite imagery. Airborne TIR overflights coupled with ${ }^{222} \mathrm{Rn}$ surveys identified multiple point-source plumes of SGD along the east coast of Spain (Mejias et al., 2012) that would have not been identified from satellite imagery alone. Airborne TIR flights performed over Nauset Marsh estuary (MA) identified high resolution, extensive diffuse SGD inputs associated with nitrate fluxes equivalent to $1-3 \mathrm{mmol} \mathrm{m}^{-2} \mathrm{~h}^{-1}$ (Portnoy et al., 1998).

Recently, airborne TIR remote sensing has shown to be useful for not only qualitative recognitions of SGD but also for quantifying groundwater fluxes from freshwater springs (Danielescu et al., 2009) and from localized point-source SGD (Kelly et al., 2013; Roseen, 2002) by estimating the thermal area of a discharge zone. Hydrologic estimates and in situ measurements of discharge have been linearly correlated to the areas of thermal plumes (Danielescu et al., 2009; Kelly et al., 2013). The resulting regression equation can be applied to extrapolate local groundwater fluxes on a regional scale and potentially reduce the amount of necessary field sampling. Danielescu et al. (2009) include diffuse seepage in their discharge calculations via MODFLOW estimates, while Kelly et al. (2013) acknowledge that their plume area ${ }^{222} \mathrm{Rn}$ derived discharge estimates underestimate total discharge by excluding diffuse SGD.

Two radionuclide tracers, radon and radium, are often used for regional scale SGD studies, providing spatially integrated measurements
(Burnett et al., 2006). Radon $\left({ }^{222} \mathrm{Rn}\right)$ and radium $\left({ }^{223,224} \mathrm{Ra}\right)$ are appropriate proxies for quantifying SGD because they have short half-lives and are naturally elevated in groundwater by several orders of magnitude relative to surface-waters. They are generated in the aquifer material from the alpha recoil of their sediment-bound parent radionuclides (Swarzenski, 2007). Additional inputs of radon and radium to the coastal water column include tidal advection, sediment diffusion, desorption and riverine input, while loss terms include mixing with depleted offshore waters, decay and, for radon, atmospheric evasion. Short lived isotopes ${ }^{224} \mathrm{Ra}\left(\mathrm{t}_{1 / 2}=3.6 \mathrm{~d}\right)$ and ${ }^{223} \mathrm{Ra}\left(\mathrm{t}_{1 / 2}=11.4 \mathrm{~d}\right)$ not only track SGD fluxes (Moore, 1996; Peterson et al., 2008) but also can be used to calculate apparent water ages (Moore, 2000). In situ ${ }^{222} \mathrm{Rn}\left(\mathrm{t}_{1 / 2}=3.8 \mathrm{~d}\right)$ measurements taken continuously along the shoreline can quickly display the spatial variation of SGD over large stretches of the coastline (Dulaiova, Peterson, Burnett, \& LaneSmith, 2005) and can provide quantitative information on the variability of SGD rate (Dulaiova, Camilli, Henderson, \& Charette, 2010). Coupling radionuclide measurements with TIR surveys has been shown to be a reliable technique for identifying and characterizing SGD over regional scales (Kelly et al., 2013; Mejias et al., 2012; Mulligan \& Charette, 2006; Peterson, Burnett, Glenn, \& Johnson, 2009; Wilson \& Rocha, 2012).

In many settings, TIR anomalies are present along specific stretches of the shoreline but absent along other shoreline segments. This study aims to quantify diffuse SGD along the north shore of Long Island, NY using airborne TIR remote sensing coupled with in situ radionuclide estimates of SGD. We propose that a mixture of fresh and circulated seawater SGD (hereafter "fresh SGD" for simplicity), driven by a positive terrestrial hydraulic gradient, produces TIR anomalies at our study sites. Locations where SGD is composed only of circulated seawater derived from tidal pumping and wave set-up lack the thermal contrast with ambient seawater necessary to be resolved by TIR imagery. Fresh SGD produced by a positive hydraulic gradient and circulated seawater sourced from tidal pumping are likely the primary acting mechanisms in coastal systems elsewhere, thus enabling the application of our method to any region where significant pore-water/surface-water temperature contrasts exist.

\section{Methods}

\subsection{Study site}

The Upper Glacial Aquifer of Long Island is an unconfined aquifer of fine to coarse-grained glacially deposited quartz sand that overlies a less permeable layer of clay deposits. Horizontal hydraulic conductivity for the outwash area of the Upper Glacial Aquifer ranges from 7 to $70 \mathrm{~m} \mathrm{~d}^{-1}$ with horizontal to vertical anisotropy between 10:1-100:1 (Buxton \& Modica, 1992). The hydraulic gradient for the Upper Glacial Aquifer is estimated to be 0.001 (Franke \& McClymonds, 1972) with a vertical hydraulic gradient between 0.02 and 0.08 in the upper meter of sediment (Bokuniewicz, Pollock, Blum, \& Wilson, 2004). Water north of Long Island's regional groundwater divide discharges into north shore harbors and embayments that exchange water with Long Island Sound (Scorca \& Monti, 2001).

SGD along the shores of Long Island, NY has been described in several locations (Beck, Rapaglia, Cochran, \& Bokuniewicz, 2007; Beck, Rapaglia, Cochran, Bokuniewicz, \& Yang, 2008; Bokuniewicz et al., 2004; Dulaiova et al., 2006; Durand, 2014; Young, 2013). Early TIR flights identified extensive diffuse groundwater discharge along the north shore of Long Island (Pluhowski, 1972). Recent work in Long Island Sound estimated $32-74 \times 10^{12} \mathrm{~L} \mathrm{y}^{-1}$ SGD via ${ }^{224} \mathrm{Ra}$ mass balance, which is approximately 1.3-3.5 times the discharge of the neighboring Connecticut River (Garcia-Orellana et al., 2014). 


\subsection{Methodology overview}

In this study airborne thermal infrared overflights were integrated with shoreline radionuclide surveys to investigate the relationship between TIR area and groundwater seepage rate along the north shore of Long Island, NY (Fig. 1). We characterized SGD in three geomorphologically distinct areas along the north shore of Long Island: Smithtown Bay (Site 1), Port Jefferson Harbor (Site 2), and eastern Suffolk County, from Mount Sinai Harbor to Mattituck Inlet (Site 3; hereafter referred to as "eastern Suffolk County"). SGD was characterized in greater detail at two locations within Smithtown Bay: a glacial outwash beach dominated by an extensive diffuse TIR anomaly (Callahan's Beach; ID \#4), and a sandy barrier beach without any TIR anomaly (Long Beach; ID \#8). At the two sites, SGD was measured via ${ }^{222} \mathrm{Rn}$ time series during September 2014; manual seepage meters were sampled during June 2014 and the subterranean estuary (STE) was sampled along a shore perpendicular transect in August 2014.

\subsection{Thermal infrared remote sensing}

A thermal infrared (TIR) overflight aboard a helicopter was performed on 16 August 2013 between 13:30 and 14:00 EST to locate areas of potential SGD into Smithtown Bay (Site 1, Fig. 1); low tide was at 13:29 EST. The flight was performed on a calm, clear day for optimal viewing conditions. A FLIR Systems T640 TIR camera was used at an altitude of $1800 \mathrm{~m}$ (pixel-to-pixel thermal accuracy $=0.1 \mathrm{~K}$, absolute accuracy $\sim 2 \mathrm{~K}$, wavelength range of 7.8-14 $\mu \mathrm{m}$, lens field of view $=25^{\circ} \times 19^{\circ}$ ); each pixel field of view covers approximately $1.2 \mathrm{~m}$ of sea surface at $1800 \mathrm{~m}$ altitude. The infrared camera was calibrated for atmospheric reflectivity and transmission prior to the flight. Visible images were taken simultaneously with thermal images using the FLIR camera. Images were taken over the shore as close to nadir as possible to reduce image obliquity. During each survey, the camera was deployed out the side of the helicopter door and operated by hand, with the lens at a minimum $150^{\circ}$ angle from normal with an attempt to keep the frame as vertical as possible. Two in situ

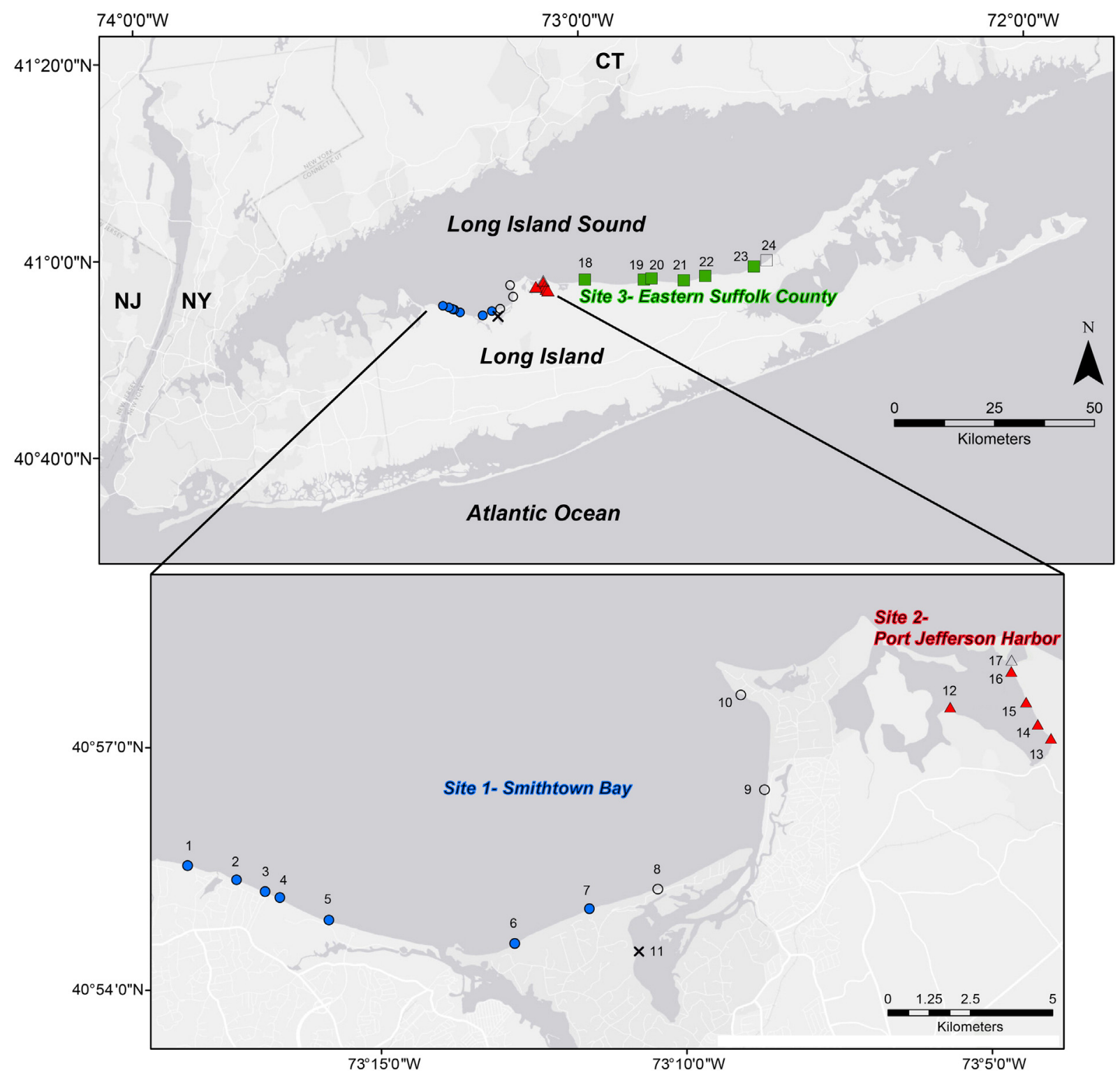

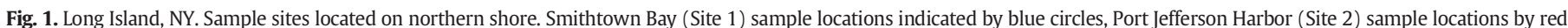

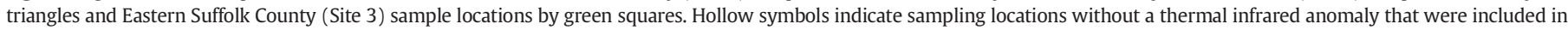

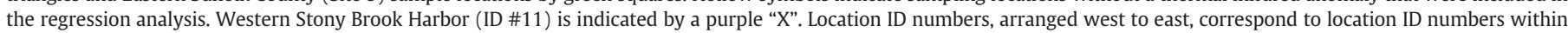
Table 1. (For interpretation of the references to color in this figure legend, the reader is referred to the web version of this article.) 
temperature-depth loggers (Solinst) were deployed during the duration of the overflight (Johnson et al., 2008). SGD studies depend upon relative temperature differences (Kelly et al., 2013), thus, we ignored absolute temperature changes as appeared to be due to factors such as the sea-surface effect, evaporative cooling, solar heating, reflected radiance as a result of a slightly oblique viewing angle, sky temperature heterogeneities, and surface water roughness.

An airborne TIR flight aboard a helicopter was conducted over Port Jefferson Harbor (Site 2, Fig. 1) on 30 July 2014 between 08:29 and 08:38 EST; low tide was at 08:16 EST. Flight data was collected at an altitude of $1150 \mathrm{~m}$ resulting in a pixel spatial resolution of $0.8 \mathrm{~m}$. An additional airborne TIR flight aboard a helicopter was conducted over eastern Suffolk County from Mount Sinai Harbor to Mattituck Inlet (Site 3, Fig. 1) on 12 September 2014 between 8:10 and 8:50 EST; low tide was at 8:09 EST. The first flight path collected data at $1800 \mathrm{~m}$ altitude and the second flight path collected data at $820 \mathrm{~m}$ altitude, resulting in a pixel spatial resolution of 1.2 and $0.5 \mathrm{~m}$, respectively.

Landsat scenes from 1990 to 2015 were selected if cloud cover was $<10 \%$, if the image scene was within $\pm 1 \mathrm{~h}$ of low tide, and if the scene was collected in a month of maximum thermal contrast between the discharging groundwater and ambient surface-waters (December, January, February, July, August, September), resulting in four Landsat 5-Thematic Mapper images (Table S1). Landsat 7 ETM + images with the scan line corrector off were excluded from the analysis. Airborne TIR imagery has been down-scaled to Landsat resolution for appropriate comparison.

\subsection{TIR image processing}

TIR images were compared to visible light imagery and to a $1 \mathrm{~m}$ contour bathymetry dataset (NOAA, 2007) to initially exclude temperature anomalies related to storm drain runoff, sewage outfall, and/or bathymetry. The thermal images were georeferenced to current NYS orthomosaics ( $0.25 \mathrm{~m}$ spatial resolution), available from New York State Orthos Online (www.orthos.dhses.ny.gov, accessed on 10/11/ 2013) using a minimum of 50 ground control points. Due to the different spatial resolutions between the orthomosaic and the airborne thermal imagery, and the slightly off-nadir pointing of the thermal imagery, a first order polynomial cubic convolution warp was applied to the airborne thermal images in order to improve the georegistration. The offshore area of an image will likely have a larger spatial error from georectification due to fewer fixed points available for georeferencing in the water; however, because all images are processed in the same manner, this error will be approximately the same between images and sites. Landsat 5 TM radiance data was converted to kinetic temperature by using Planck's law and a constant emissivity value of 0.98 for water. No correction for atmospheric effects was made.

Multiple temperature profiles were arbitrarily created across an individual georectified infrared image in order to delineate the boundary temperature between SGD and ambient surface-waters (Kelly et al., 2013). The boundary temperature was conservatively defined as the maximum rate of change in temperature, relative to pixel distance, within $0.1{ }^{\circ} \mathrm{C}$ (the cameras pixel-to-pixel TIR accuracy). The average of the profile boundary temperatures was taken to define the offshore spatial extent of SGD (see Section 3.1.1). The landward boundary of the diffuse seepage zone was taken where the thermal signal ended in shallow water against the beach or against docks and jetties, and is represented by the coolest part of the temperature profiles. Region of interest polygons were created over each TIR scene to calculate the pixel temperature distribution (see Fig. 2 for example). The surface area of each SGD TIR anomaly was calculated as the cumulative sum of each pixel within the region of interest below the defined boundary temperature. Kelly et al. (2013); Danielescu et al. (2009) and Roseen (2002) successfully used similar methodologies for calculating TIR area.

Error associated with georectification and with TIR area calculations should be included in any SGD vs. TIR area regression equation. Thermal areas calculated from the region of interest polygons varied by a maximum of $1.3 \%$ ( $n=5$; i.e. Fig. $2 \mathrm{~A}$ ), suggesting that the areal extent of the region of interest polygons had a negligible effect on the calculated discharge area. A more sophisticated nadir-viewing pixel detector array with an inertial navigation system and global positioning system (Johnson et al., 2008; Kelly et al., 2013; Mejias et al., 2012) will reduce geometric error, although this system is much more expensive than the one employed in the present study.

\subsection{Shoreline radionuclide surveys}

TIR images were used to select locations for radium $\left({ }^{223,224} \mathrm{Ra}\right)$ surface-water sample collection at low tide directly following the August 2013 Smithtown Bay flight (Site 1, Fig. 1); additional samples were taken further offshore. Pore-water was concurrently sampled from approximately $1 \mathrm{~m}$ depth along the low tide mark of the beach face in order to measure end-member Ra concentrations (Beck et al., 2008). Water samples (20-40 L) were collected in plastic carboys and filtered through $\mathrm{MnO}_{2}$ impregnated acrylic fibers. Filters were immediately returned to the lab to be counted on a radium delayed coincidence counter (Moore \& Arnold, 1996) in order to measure the short-lived ${ }^{224} \mathrm{Ra}$ isotope. The system was calibrated by measuring standards of known activities of ${ }^{232} \mathrm{Th}$ adsorbed on a $\mathrm{MnO}_{2}$ fiber column (Moore \& Arnold, 1996). A second measurement was performed approximately 10 days later in order to quantify ${ }^{223} \mathrm{Ra}$. The efficiency of the system for counting ${ }^{223} \mathrm{Ra}$ was determined following the methods outlined by Moore and Cai (2013). Multiple standards and background readings were taken before, between, and after analysis of the samples. Propagation of uncertainties for radium analysis was calculated following the methodology outlined in Garcia-Solsona, Garcia-Orellana, Masque, and Dulaiova (2008).

A continuous ${ }^{222}$ Rn survey (Dulaiova et al., 2005) was performed on 20 June 2013 during low tide along the shoreline of Smithtown Bay (Site 1) and on 6 September 2014 along eastern Suffolk County, from Mount Sinai Harbor to Mattituck Inlet (Site 3, Fig. 1). A continuous ${ }^{222}$ Rn survey was conducted in Port Jefferson Harbor (Site 2, Fig. 1) during August 2012 (Young, Tamborski, \& Bokuniewicz, 2015). Surface-water was pumped $\left(\sim 2 \mathrm{~L} \mathrm{~min}^{-1}\right)$ through a gas exchange membrane module (Liquicel Co.) (Dulaiova et al., 2010; Schubert, Paschke, Lieberman, \& Burnett, 2012) in order to strip ${ }^{222} \mathrm{Rn}$ gas out of the water phase to a commercial radon-in-air monitor (RAD7, Durridge Co.) with a set integration time of ten minutes, while traveling at a constant boat speed of approximately three knots. The RAD7 counts the $\alpha$-decay of ${ }^{222} \mathrm{Rn}$ by measuring the activity of its short-lived daughters, ${ }^{218} \mathrm{Po}$ and ${ }^{214} \mathrm{Po}$ via their energy discrimination into energy specific windows (Burnett \& Dulaiova, 2003). Atmospheric ${ }^{222} \mathrm{Rn}$ measurements were made before the survey while wind speed was continually monitored using a handheld anemometer (Kestrel). ${ }^{222} \mathrm{Rn}$ activity in water was calculated based on a known temperature and salinity dependence function (Schubert et al., 2012). A laboratory calibrated YSI 556 handheld multi-parameter probe with flow-through cell capability was used to record water temperature, salinity, dissolved oxygen, and oxidationreduction potential continuously along the survey track while position was monitored with a GPS.

\subsection{Site inter-comparison}

${ }^{222} \mathrm{Rn}$ surface-water activities were monitored for a $24 \mathrm{~h}$ period (Burnett \& Dulaiova, 2003) at Callahan's Beach (ID \#4; Site 1, Smithtown Bay) and Long Beach (ID \#8; Site 1, Smithtown Bay) in September 2014. Surface-water was continually pumped and fed into an air-water exchanger, as described above, recording a ${ }^{222} \mathrm{Rn}$ measurement every hour. SGD was directly measured using vented, benthic chambers (a.k.a. "seepage meters") (Lee, 1977) in a shoreperpendicular transect ( $\mathrm{n}=4$ seepage meters) in June 2014. At Callahan's Beach, seepage meters S1-S4 were placed 10, 21, 25, and 

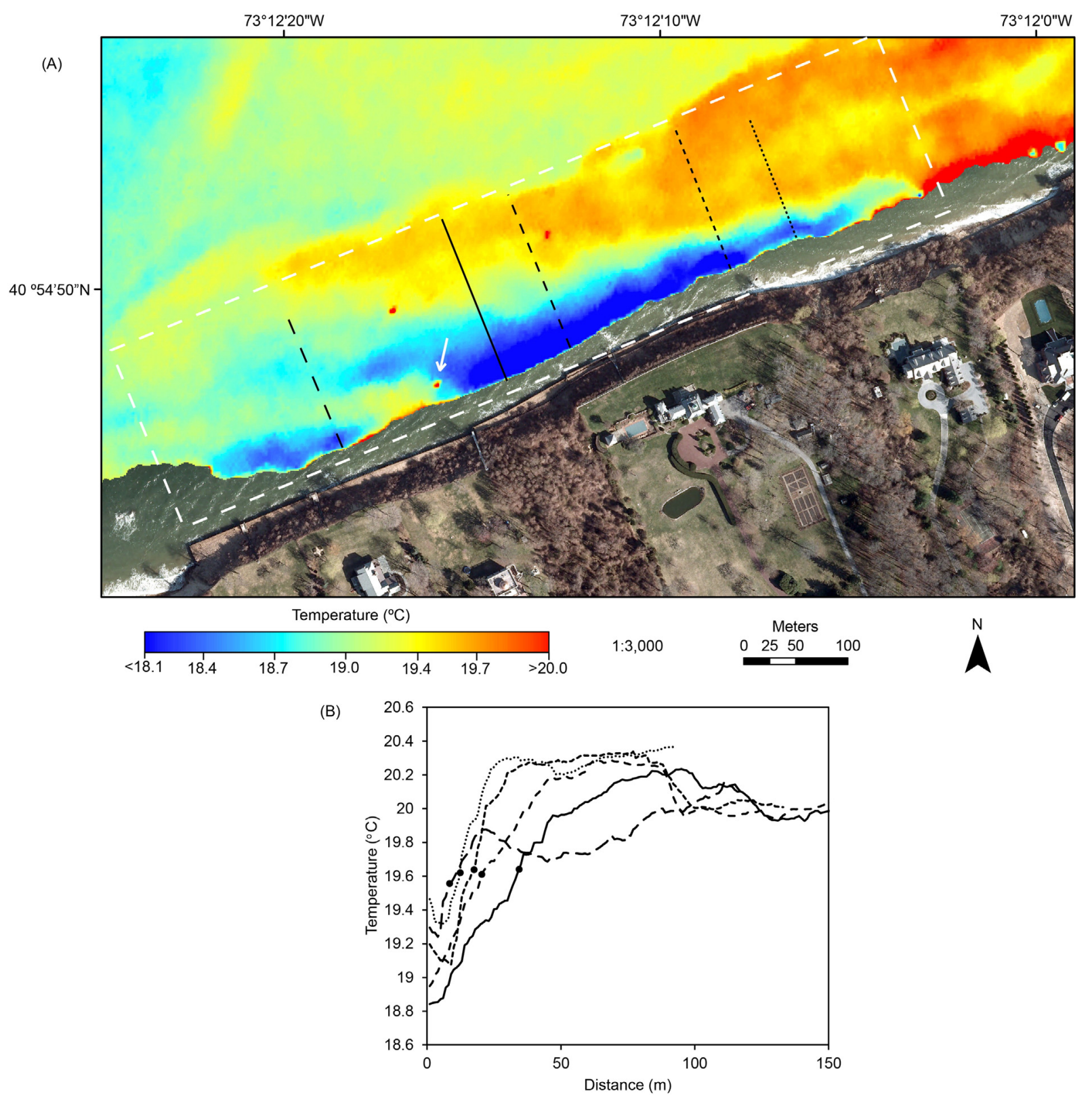

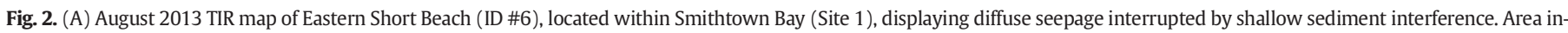

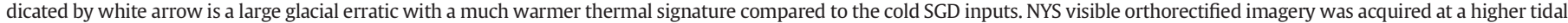

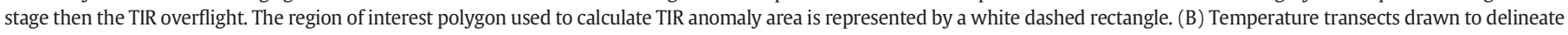
the SGD/surface-water boundary temperature. Calculated boundaries temperatures are indicated by black circles.

$12 \mathrm{~m}$ offshore, respectively. At Long Beach, meters S1-S4 were placed $15,19,25$, and $17.5 \mathrm{~m}$ offshore, respectively. The fourth seepage meter was placed approximately $3 \mathrm{~m}$ next to the first seepage meter in the longshore direction in order to assess small scale seepage variability (Michael, Lubetsky, \& Harvey, 2003). Seepage meters were placed approximately $10 \mathrm{~cm}$ into the sediment and allowed to equilibrate for at least $24 \mathrm{~h}$ prior to sampling to ensure complete flushing of seawater (seepage meter headspace was less than $10 \mathrm{~cm}$, and average seepage rates were $\gg 10 \mathrm{~cm} \mathrm{~d}^{-1}$ ). Collection bags were not prefilled (Shaw \& Prepas, 1989) in order to measure the salinity and nutrient concentrations of the discharging fluid. Seepage meter samples were filtered $(0.45 \mu \mathrm{m})$ and analyzed via Lachat Quickchem 8000 + FIA series.

An intertidal transect of monitoring wells screened at multiple depths was sampled in August 2014 to directly sample pore-waters in the subterranean estuary (STE). Monitoring wells were located at Callahan's Beach and Long Beach, with multi-level wells positioned at the low tide mark, an intertidal location, and at the high water mark of the beach. Wells were sampled via peristaltic pump after sufficient well purging, during low tide. A YSI 556 handheld multi-parameter probe was used to measure water quality parameters, as described in Section 2.5.

\subsection{Calculating SGD, apparent water ages \& residence times}

${ }^{222} \mathrm{Rn}$ shoreline surveys were converted into SGD fluxes following the revised methods of Dulaiova et al. (2010). Excess ${ }^{222} \mathrm{Rn}\left(\mathrm{Bq} \mathrm{m}^{-3}\right)$ was calculated as the ${ }^{222} \mathrm{Rn}$ unsupported by parent ${ }^{226} \mathrm{Ra}$ decay:

${ }^{222} \mathrm{Rn}_{\text {excess }}={ }^{222} \mathrm{Rn}_{\text {total }}-{ }^{226} \mathrm{Ra}$

${ }^{226}$ Ra surface-water samples collected in Smithtown Bay (Site 1) and across the axial transect of Long Island Sound (mean $=1.53 \mathrm{~Bq} \mathrm{~m}^{-3}$, 
$\mathrm{n}=26$ ) were used to calculate excess ${ }^{222} \mathrm{Rn}$ (Garcia-Orellana et al., 2014). A ${ }^{222} \mathrm{Rn}$ inventory was calculated by multiplying each excess ${ }^{222} \mathrm{Rn}$ measurement by the water column depth $(\mathrm{z})$.

${ }^{222} \mathrm{Rn}_{\text {inventory }}={ }^{222} \mathrm{Rn}_{\text {excess }} * \mathrm{Z}$

The ${ }^{222} \mathrm{Rn}_{\text {inventory }}$ calculation assumes that ${ }^{222} \mathrm{Rn}$ is distributed homogeneously throughout the water column. This assumption is valid in shallow, well mixed coastal systems, such as our three sites analyzed here. The maximum depth observed during the three shoreline radionuclide surveys was $2.5 \mathrm{~m}$, which is assumed to represent a wellmixed water column. In deeper offshore and lower energy environments where water column stratification occurs, this assumption may not necessarily be valid. The radioactive decay constant $(\lambda)$ of ${ }^{222} \mathrm{Rn}$ $\left(0.18 \mathrm{~d}^{-1}\right)$ was multiplied by ${ }^{222} \mathrm{Rn}_{\text {inventory }}$ to produce a steady-state coastal ${ }^{222} \mathrm{Rn}$ flux $\left(\mathrm{Bq} \mathrm{\textrm {m } ^ { - 2 }} \mathrm{d}^{-1}\right)$.

${ }^{222} \mathrm{Rn}_{\text {Steady-State Flux }}={ }^{222} \mathrm{Rn}_{\text {inventory }} * \lambda$

${ }^{222} \mathrm{Rn}$ loss via atmospheric evasion was corrected for using a stagnant film model (MacIntyre, Wanninkhof, \& Chanton, 1995) (Jatm; $\mathrm{Bq} \mathrm{m}{ }^{-2} \mathrm{~d}^{-1}$ ), where $k$ is the gas transfer coefficient of ${ }^{222} \mathrm{Rn}, C_{w}$ and $C_{a t m}$ are the concentration of ${ }^{222} \mathrm{Rn}$ in the water column and atmosphere respectively, and $\alpha$ is Oswald's solubility coefficient.

$J_{\mathrm{atm}}=k *\left(C_{w}-\alpha * C_{\mathrm{atm}}\right)$

Atmospheric evasion and tidal mixing losses $\left(J_{\text {mix }}\right)$ are added back into each steady-state coastal ${ }^{222} \mathrm{Rn}$ flux measurement as:

${ }^{222} \mathrm{Rn}_{\text {Corrected Flux }}={ }^{222} \mathrm{Rn}_{\text {Steady-State Flux }}+J_{\text {atm }}+J_{\text {mix }}$

Sediment diffusion inputs are anticipated to be small and were excluded from this analysis. ${ }^{222} \mathrm{Rn}$ diffusive fluxes were experimentally determined to be $1.3 \mathrm{~Bq} \mathrm{~m}^{-2} \mathrm{~d}^{-1}$ from a core incubation experiment taken at West Meadow Beach (ID \#9, Site 1) (Tamborski, 2014). Assuming steady-state conditions, this flux would support less than $5 \%$ of the observed ${ }^{222} \mathrm{Rn}$ inventory, which is in strong agreement with experimental data from Waquoit Bay, MA (Dulaiova et al., 2010). The corrected ${ }^{222} \mathrm{Rn}$ flux was divided by a shallow groundwater endmember $\left({ }^{222} R n_{g w}\right)$ to calculate SGD rate $\left(\mathrm{m} \mathrm{d}^{-1}\right)$.

$Q_{\text {sgd }}=\frac{{ }^{222} R n_{\text {Corrected }- \text { Flux }}}{{ }^{222} R n_{\text {gw }}}$.

In Smithtown Bay, we used a brackish endmember for measurements taken where TIR anomalies were observed; the average salinity and ${ }^{222} \mathrm{Rn}$ activity of the Callahan's Beach low tide wells was 24.0 and $789 \pm 258 \mathrm{~Bq} \mathrm{~m}^{-3}(\mathrm{n}=5)$, respectively. A saline endmember was chosen for site locations where there was no observable TIR anomaly, taken as the average of the Long Beach low tide wells with a salinity and ${ }^{222} \mathrm{Rn}$ activity equal to 27.8 and $1554 \pm 168 \mathrm{~Bq} \mathrm{~m}^{-3}(\mathrm{n}=6)$, respectively. For the eastern Suffolk County survey, we use an average endmember sampled from shallow push-point piezometers (salinity $=18.0 ;{ }^{222} \mathrm{Rn}$ average $=1740 \mathrm{~Bq} \mathrm{~m}^{-3} ;$ range $\left.=1530-1950 \mathrm{~Bq} \mathrm{~m}^{-3} ; \mathrm{n}=2\right)$.

Time-series SGD vertical advective velocities for Callahan's Beach and Long Beach were calculated by assessing the change in the water column ${ }^{222} \mathrm{Rn}$ inventory (Eq. (2)) with respect to time (Burnett \& Dulaiova, 2003). Net ${ }^{222} \mathrm{Rn}$ fluxes were calculated as the sum of the hourly ${ }^{222} \mathrm{Rn}$ flux, atmospheric loss, ebb tide loss and flood tide gain for each hourly time interval. Tidal losses were estimated as the net flux loss of ${ }^{222} \mathrm{Rn}$ over the tidal sampling period (Burnett \& Dulaiova, 2003).

${ }^{224} \mathrm{Ra}$ SGD fluxes were calculated similarly to the ${ }^{222} \mathrm{Rn}$ shoreline surveys, except that the term for atmospheric loss was not needed (Peterson et al., 2008). A measured offshore value of $1.7 \mathrm{~Bq}^{228} \mathrm{Th} \mathrm{m}^{-3}$
( $\mathrm{n}=4)$ was subtracted from all surface water samples to determine excess ${ }^{224} \mathrm{Ra}$. Because nearshore residence times were anticipated to be short, we used the activity ratios of ${ }^{224} \mathrm{Ra}$ and ${ }^{223} \mathrm{Ra}$ in surface-water and pore-water to calculate the surface-waters apparent radium water age (Moore, 2000; Tovar-Sanchez et al., 2014) as:

$t=\ln \frac{A R p w}{A R s w} * \frac{1}{\lambda_{224}-\lambda_{223}}$

where $t$ is the apparent radium age of the surface water, $A R_{p w}$ and $A R_{s w}$ are the measured 224/223 radium activity ratios in pore-water and surface-water, respectively, and the $\lambda s$ are the radium isotope decay constants.

At steady-state the residence time, $\mathrm{T}$, of pore-water using radium isotopes (Bokuniewicz et al., in press) is:

$[\mathrm{Ra}]^{\mathrm{T}}=[\mathrm{Ra}]^{\mathrm{o}} * \mathrm{e}^{-\lambda \mathrm{T}}+[\mathrm{Ra}]^{\mathrm{eq} \cdot} *\left(1-\mathrm{e}^{-\lambda \mathrm{T}}\right)$

where $\mathrm{T}$ is the pore-water residence time, $[\mathrm{Ra}]^{\mathrm{T}}$ is the activity of ${ }^{224} \mathrm{Ra}$ at time $\mathrm{T},[\mathrm{Ra}]^{\mathrm{O}}$ is the activity of ${ }^{224} \mathrm{Ra}$ of the surface-waters infiltrating the beach face at high tide, [Ra] ${ }^{\text {eq. }}$ is the activity of ${ }^{224} \mathrm{Ra}$ at steady state, and $\lambda$ is the ${ }^{224} \mathrm{Ra}$ decay constant. An additional Ra input term would be required in Eq. (8) if deeper groundwater had mixed with the shallow, circulated pore-water. Inclusion of this additional Ra term would result in shorter calculated residence times.

Uncertainty in calculating SGD determined by radionuclide measurements are well understood (Burnett, Santos, Weinstein, Swarzenski, \& Herut, 2007; Garcia-Solsona et al., 2008). The largest source of uncertainty in an SGD study is generally the radionuclide activity of the groundwater endmember (Burnett et al., 2007), which may be both spatially and temporally variable (Luek \& Beck, 2014). In this study, a total of 13 endmembers were used, which has been suggested to adequately capture the "mean" endmember activity (12 endmembers or greater; Sadat-Noori, Santos, Sanders, Sanders, \& Maher, 2015). For any radionuclide, mixing losses with offshore waters will introduce error while ${ }^{222} \mathrm{Rn}$ loss via atmospheric evasion can create greater errors at higher wind speeds. Where fine-grained sediments are present, fluxes of ${ }^{222} \mathrm{Rn}$ and ${ }^{224} \mathrm{Ra}$ mediated by diffusion or bioturbation can represent a significant input source to surface waters (GarciaOrellana et al., 2014).

\section{Results}

\subsection{Thermal infrared remote sensing}

\subsubsection{Airborne TIR remote sensing}

The thermal infrared overflights revealed spatially variable, nonpoint source diffuse SGD occurring along the north shore of Long Island (Fig. 1). Shore-perpendicular temperature transects showed significant cold-water inputs, presumably due to SGD, creating localized nearshore temperature anomalies (Figs. 2, 3). Twenty-five TIR anomalies were identified, seven within Smithtown Bay (Site 1), eleven in Port Jefferson Harbor (Site 2) and seven along eastern Suffolk County (Site 3). In Port Jefferson Harbor, four temperature anomalies located in the southern portion of the harbor were associated with a storm drain and sewage outfall from the Port Jefferson Sewage Treatment Plant (Fig. 4). Two additional anomalies located on the western shoreline were associated with bathymetry and where stands of Spartina alterniflora were found. These temperature anomalies were not used in the subsequent analysis. The five remaining temperature anomalies in Port Jefferson Harbor were considered to be due to SGD, located on the eastern and southern portions of the harbor (Fig. 4). 

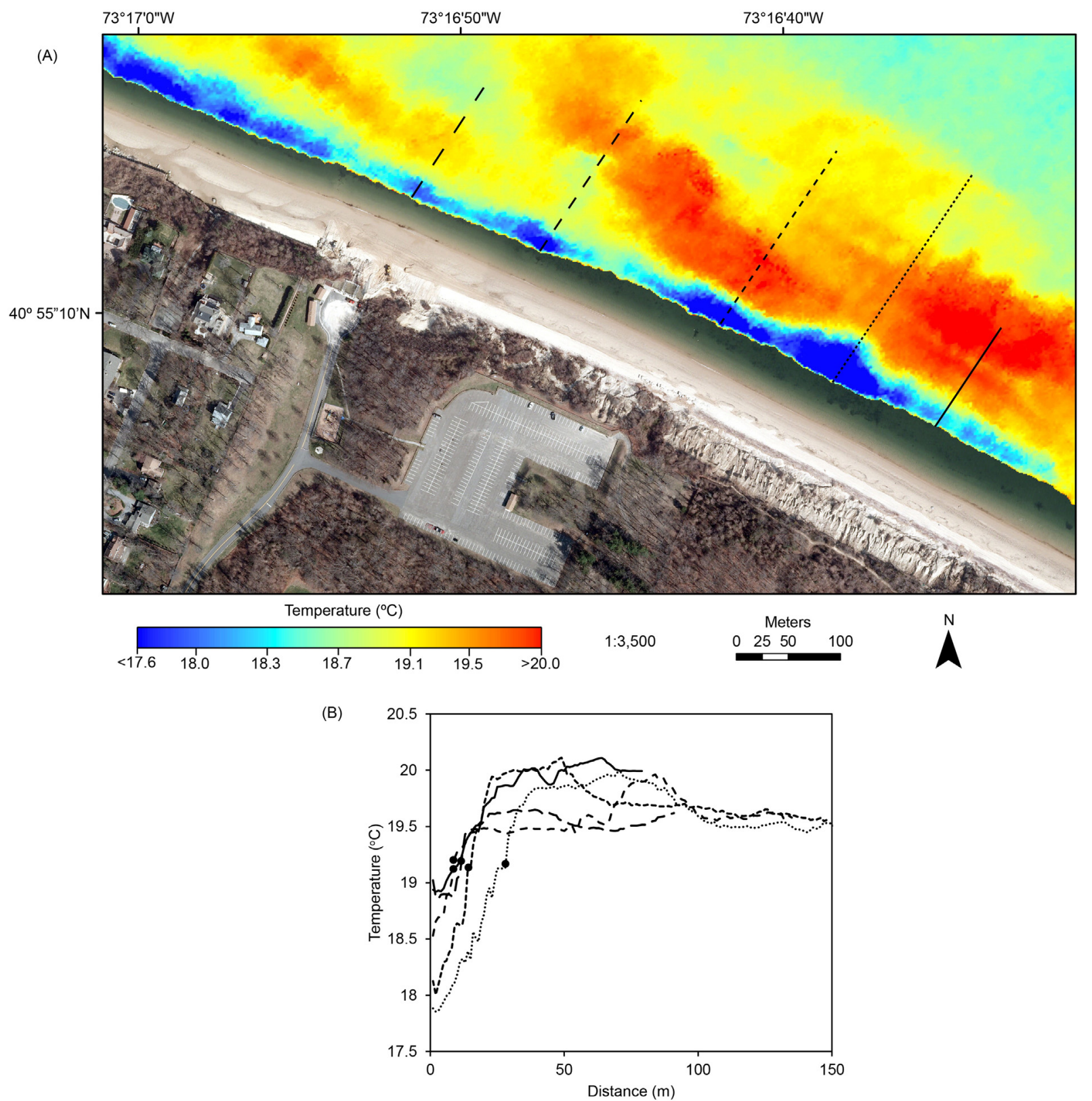

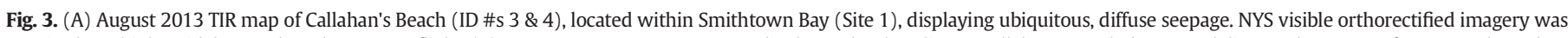

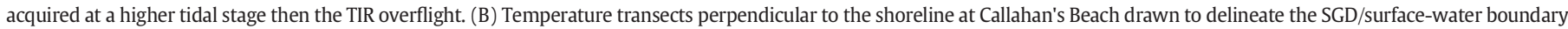
temperature. Calculated boundaries temperatures are indicated by black circles.

Following Wilson and Rocha (2012), we define the observed temperature anomalies relative to the ambient surface-waters:

$\Delta \mathrm{T}=\mathrm{T}_{\text {Boundary }}-\mathrm{T}_{\text {Offshore }}$

where $T_{\text {Boundary }}$ is the defined boundary temperature for each location and $\mathrm{T}_{\text {Offshore }}$ is the average surface-water pixel temperature observed offshore for each scene. Smithtown Bay (Site 1) $\Delta \mathrm{T}$ ranged from -0.6 to $-1.4{ }^{\circ} \mathrm{C}$; Port Jefferson Harbor (Site 2) $\Delta \mathrm{T}$ ranged from -0.7 to $-1.6^{\circ} \mathrm{C}$ and eastern Suffolk County (Site 3) $\Delta \mathrm{T}$ varied from -1.1 to $-2.1{ }^{\circ} \mathrm{C}$ (Table 1). The area of cool TIR anomalies measured within Smithtown Bay varied from 2020 to $23,260 \mathrm{~m}^{2}$ (Table 1). In Port Jefferson Harbor, TIR surface areas ranged from 1930 to $9660 \mathrm{~m}^{2}$ while thermal areas for eastern Suffolk County were between 2470 to $9310 \mathrm{~m}^{2}$ (Table 1). Except for Long Beach Bluffs (ID \#7, Site 1), $\Delta \mathrm{T}$ was linearly correlated with TIR anomaly area $\left(R^{2}=0.60\right.$, for all sites), signifying that larger TIR anomalies were due to the input of cooler temperature pore-waters. There were no large differences between the $\Delta \mathrm{T}$ vs TIR anomaly area slopes for the three different study sites (Fig. S1). Of the 18 observed TIR anomalies, four were artificially bound by docks or jetties (ID \#2, Site 1; ID \#s 12 \& 14, Site 2; ID \#23, Site 3).

All three TIR overflights revealed several locations on the north shore of Long Island without any nearshore temperature anomaly. Of the $18 \mathrm{~km}$ shoreline imaged within Smithtown Bay, approximately $85 \%$ of the shoreline lacked any TIR anomaly, while $84 \%$ of the $7.5 \mathrm{~km}$ long Port Jefferson Harbor shoreline lacked any TIR anomaly. In the ensuing discussion, we focus on Long Beach (Section 4.1; Fig. 5).

\subsubsection{Satellite TIR remote sensing}

The $60 \mathrm{~m}$ (resampled from $120 \mathrm{~m}$ ) spatial resolution of Landsat 5TM TIR data is inadequate for accurately resolving diffuse SGD along Long Island (Fig. 6). Of the 18 TIR anomalies identified during the various airborne overflights, none were identifiable from the Landsat data. 


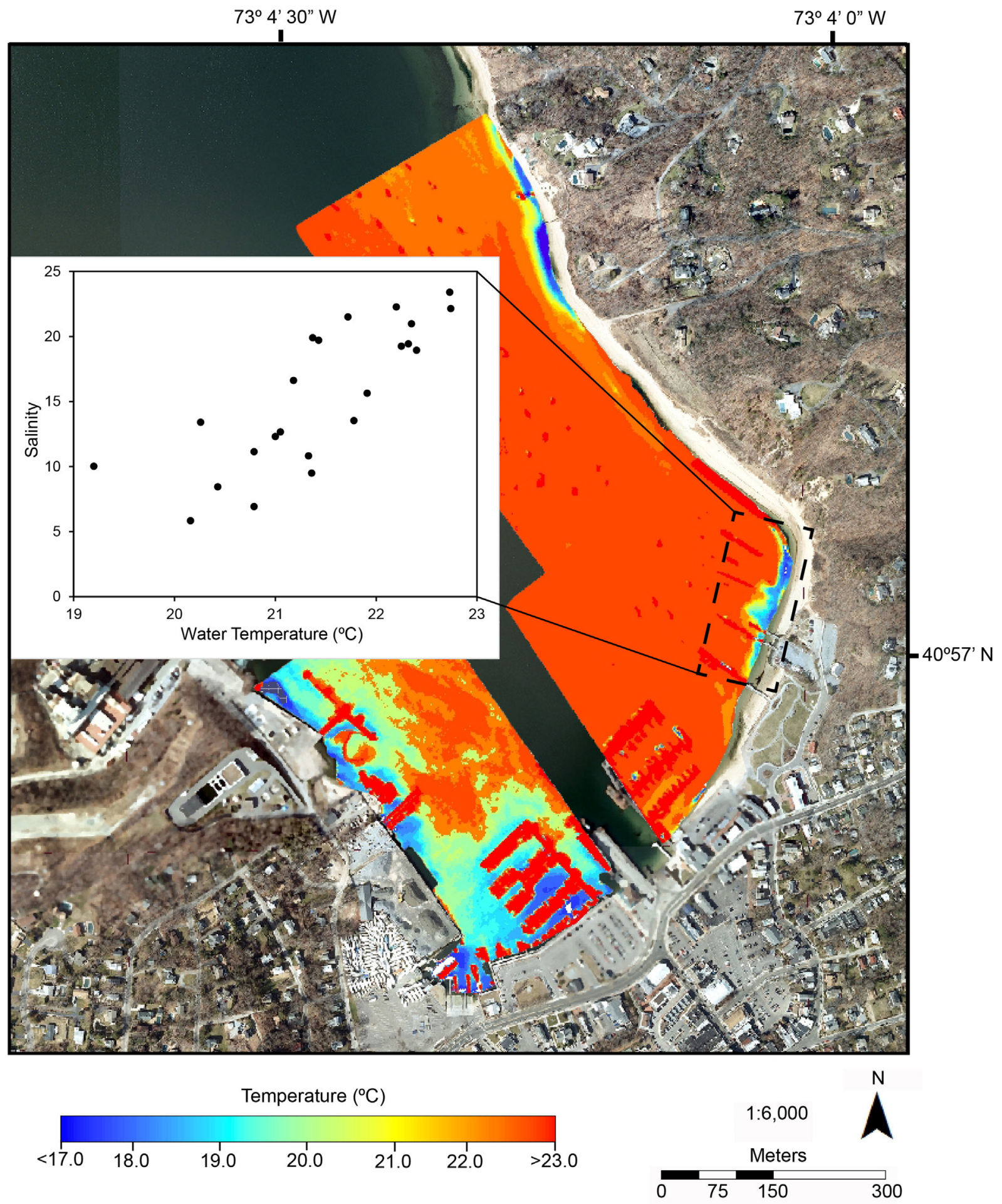

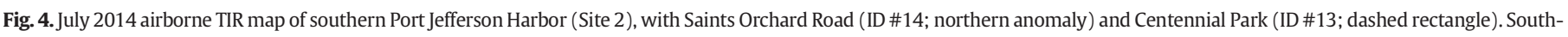

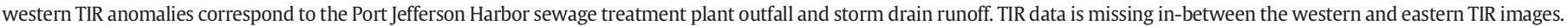
Inset: In situ nearshore surface-water temperature-salinity distribution for Centennial Park.

In order for thermal imagery to be used as a qualitative indicator of diffuse SGD on Long Island, the thermal images need to have a minimum spatial resolution of $30 \mathrm{~m}$, and $15 \mathrm{~m}$ resolution to be used in a quantitative analysis (Fig. 6). TIR detection of SGD temperature anomalies will ultimately depend upon the size of the anomaly; here, the average Long Island TIR anomaly falls below the Landsat TIR detection limit.

\subsection{Shoreline radionuclide surveys}

${ }^{224}$ Ra surface-water activities within Smithtown Bay (Site 1) ranged from 3.8 Bq m$~^{-3}$ at Eastern Short Beach (ID \#6) to $16.2 \mathrm{~Bq} \mathrm{~m}^{-3}$ at Long Beach Bluffs (ID \#7), measured at the sites of TIR anomalies. ${ }^{224}$ Ra porewater activities, measured adjacent to the surface-water samples at the 


\section{Table 1}

Sample locations with their associated TIR properties, as measured by the various airborne TIR overflights. $\Delta \mathrm{T}$ is calculated as the difference between each TIR anomaly boundary temperature and the average offshore temperature. TIR Area is the 2-dimensional spatial extent of the observed TIR anomalies. Location ID numbers correspond to Fig. 1.

\begin{tabular}{|c|c|c|c|}
\hline \multirow[t]{2}{*}{ Location } & \multirow[t]{2}{*}{ ID } & \multirow[t]{2}{*}{$\Delta \mathrm{T}$} & \multirow{2}{*}{$\frac{\text { TIR area }}{\mathrm{m}^{2}}$} \\
\hline & & & \\
\hline \multicolumn{4}{|l|}{ Smithtown Bay - Site 1} \\
\hline Makamah West & 1 & -1.1 & 2070 \\
\hline Makamah East & 2 & -0.8 & 5390 \\
\hline Callahan's Beach West & 3 & -0.9 & 4620 \\
\hline Callahan's Beach East & 4 & -0.9 & 4320 \\
\hline Sunken Meadow Bluffs & 5 & -0.6 & 2020 \\
\hline Eastern Short Beach & 6 & -1.4 & 8220 \\
\hline Long Beach Bluffs & 7 & -1.1 & 23,260 \\
\hline Long Beach & 8 & $\mathrm{n} / \mathrm{a}$ & 0 \\
\hline West Meadow Beach & 9 & $\mathrm{n} / \mathrm{a}$ & 0 \\
\hline Crane Neck & 10 & $\mathrm{n} / \mathrm{a}$ & 0 \\
\hline \multicolumn{4}{|c|}{ Port Jefferson Harbor - Site 2} \\
\hline Van Brunt Manor Road & 12 & -1.2 & 4740 \\
\hline Centennial Park & 13 & -1.6 & 5800 \\
\hline Saints Orchard Road & 14 & -0.9 & 9660 \\
\hline Molts Hollow Road & 15 & -0.7 & 2470 \\
\hline Anchorage Road & 16 & -0.7 & 1930 \\
\hline McAllister Park & 17 & $\mathrm{n} / \mathrm{a}$ & 0 \\
\hline \multicolumn{4}{|c|}{ Eastern Suffolk County - Site 3} \\
\hline Miller Place & 18 & -1.4 & 9220 \\
\hline Wading River West & 19 & -1.4 & 4280 \\
\hline Wading River East & 20 & -1.1 & 3610 \\
\hline Beach Way Marsh & 21 & -1.3 & 9310 \\
\hline Baiting Hollow & 22 & -2.1 & 7460 \\
\hline Northville & 23 & -1.1 & 2480 \\
\hline Mattituck Inlet & 24 & $\mathrm{n} / \mathrm{a}$ & 0 \\
\hline
\end{tabular}

low tide mark, ranged from $28.3 \mathrm{~Bq} \mathrm{~m}{ }^{-3}$ at Eastern Short Beach (ID \#6) to $63.2 \mathrm{~Bq} \mathrm{~m}^{-3}$ at Callahan's Beach West (ID \#3). ${ }^{224} \mathrm{Ra}$ uncertainties were calculated to be $\pm 6 \%$ (Garcia-Solsona et al., 2008). Surface-water excess ${ }^{222} \mathrm{Rn}$ varied from $8.6 \mathrm{~Bq} \mathrm{~m}{ }^{-3}$ at Crane Neck (ID \#10) to $53.5 \mathrm{~Bq} \mathrm{~m}^{-3}$ at Makamah East (ID \#2). Due to the spatial and temporal integration of the ${ }^{222} \mathrm{Rn}$ measurements, uncertainties were as large as 56\%. SGD rates calculated from the August 2013 Smithtown Bay radionuclide surveys range from 2.1 to $16.2 \mathrm{~cm} \mathrm{~d}^{-1}$ within the TIR anomalies, with a near $1: 1$ relationship between ${ }^{222} \mathrm{Rn}$ and ${ }^{224} \mathrm{Ra}$ estimates ( lope $=0.93 ; \mathrm{R}^{2}=0.98$ ). ${ }^{222} \mathrm{Rn}$ and ${ }^{224} \mathrm{Ra}$ results for Smithtown Bay are summarized in Tables 2 \& 3, respectively. Average pore-water residence times equal $1.3 \pm 0.4 \mathrm{~d}$ when $[\mathrm{Ra}]^{\circ}$ is set to $5 \mathrm{~Bq} \mathrm{~m}{ }^{-3}$, and assuming [Ra] ${ }^{\text {eq }}$ of $184 \mathrm{~Bq} \mathrm{~m}^{-3}$ (Bokuniewicz et al., in press) (Table 3). For the September 2014 eastern Suffolk County survey, surface-water excess ${ }^{222} \mathrm{Rn}$ ranged from 11.7 to $27.4 \mathrm{~Bq} \mathrm{~m}{ }^{-3} .{ }^{222} \mathrm{Rn}$ SGD estimates within TIR anomalies ranged from 4.7 to $9.5 \mathrm{~cm} \mathrm{~d}^{-1}$. SGD was only $1.4 \mathrm{~cm} \mathrm{~d}^{-1}$ at Mattituck Inlet (ID \#24), where no anomaly was observed (Table 2).

${ }^{222} \mathrm{Rn}$ estimates of SGD for Port Jefferson Harbor in August 2012 have been previously calculated by Young et al. (2015). SGD outside of TIR anomalies averaged $1.6 \mathrm{~cm} \mathrm{~d}^{-1}$, while SGD in locations within TIR anomalies varied from 2.3 to $13.0 \mathrm{~cm} \mathrm{~d}^{-1}$. Surface-water radionuclide and SGD results for Port Jefferson Harbor and eastern Suffolk County are presented in Table 2 .

\subsection{TIR area $v s . S G D$}

There was a strong, positive linear relationship between the area of diffuse TIR anomalies and SGD rate calculated from the shoreline radionuclide surveys (Fig. 7A), signifying that zones of spatially extensive thermal anomalies experienced greater SGD. The use of two independent radionuclide tracers $\left({ }^{224} \mathrm{Ra}\right.$ and $\left.{ }^{222} \mathrm{Rn}\right)$ for our analysis in Smithtown Bay has provided an extra level of confidence in our results. We excluded ${ }^{223}$ Ra from our analysis because measurement of ${ }^{224}$ Ra has less uncertainty (Garcia-Solsona et al., 2008), however, ${ }^{223} \mathrm{Ra}$ and ${ }^{224} \mathrm{Ra}$ exhibit a positive linear relationship, suggesting that all three isotopes

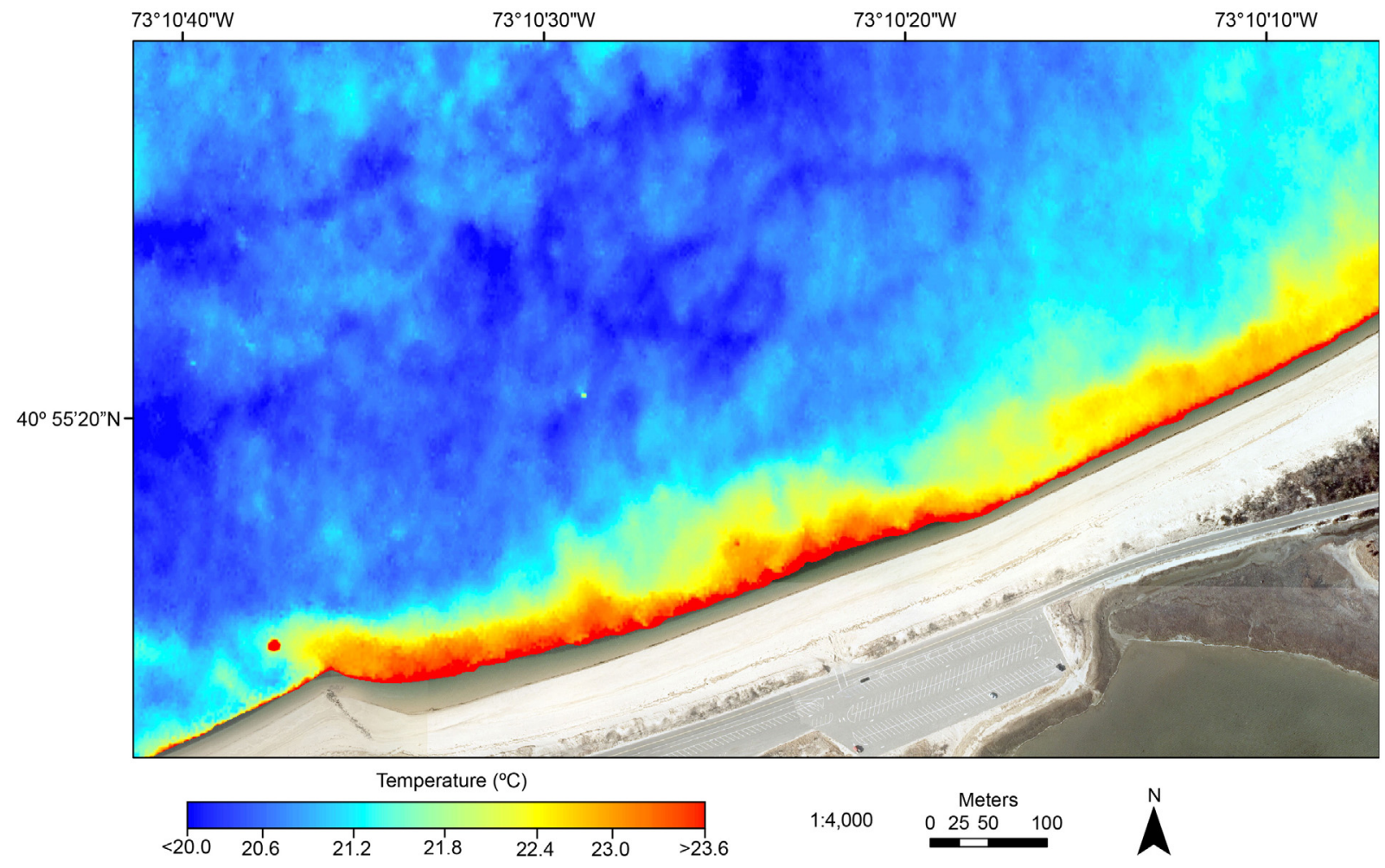

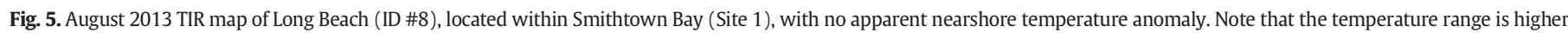
than the previous figures. NYS visible orthorectified imagery was acquired at a higher tidal stage than the TIR overflight. 


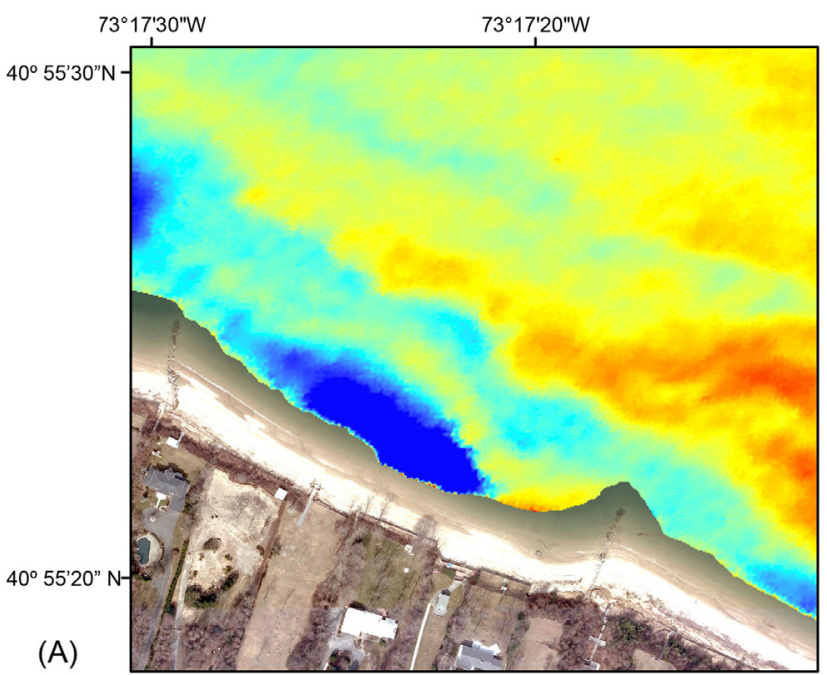

(C)

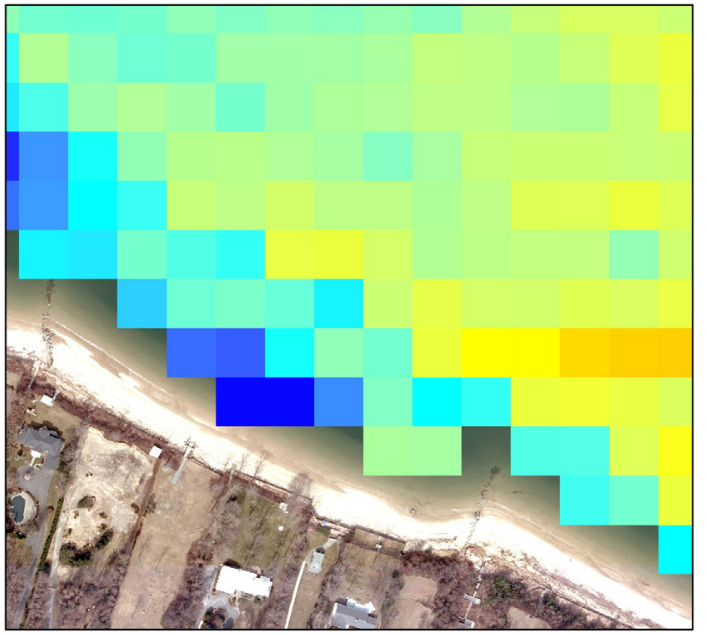

(B)

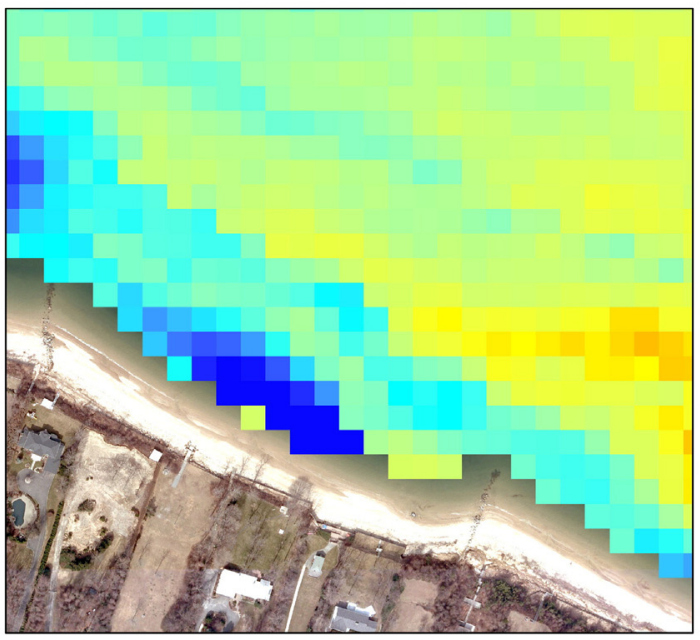

(D)
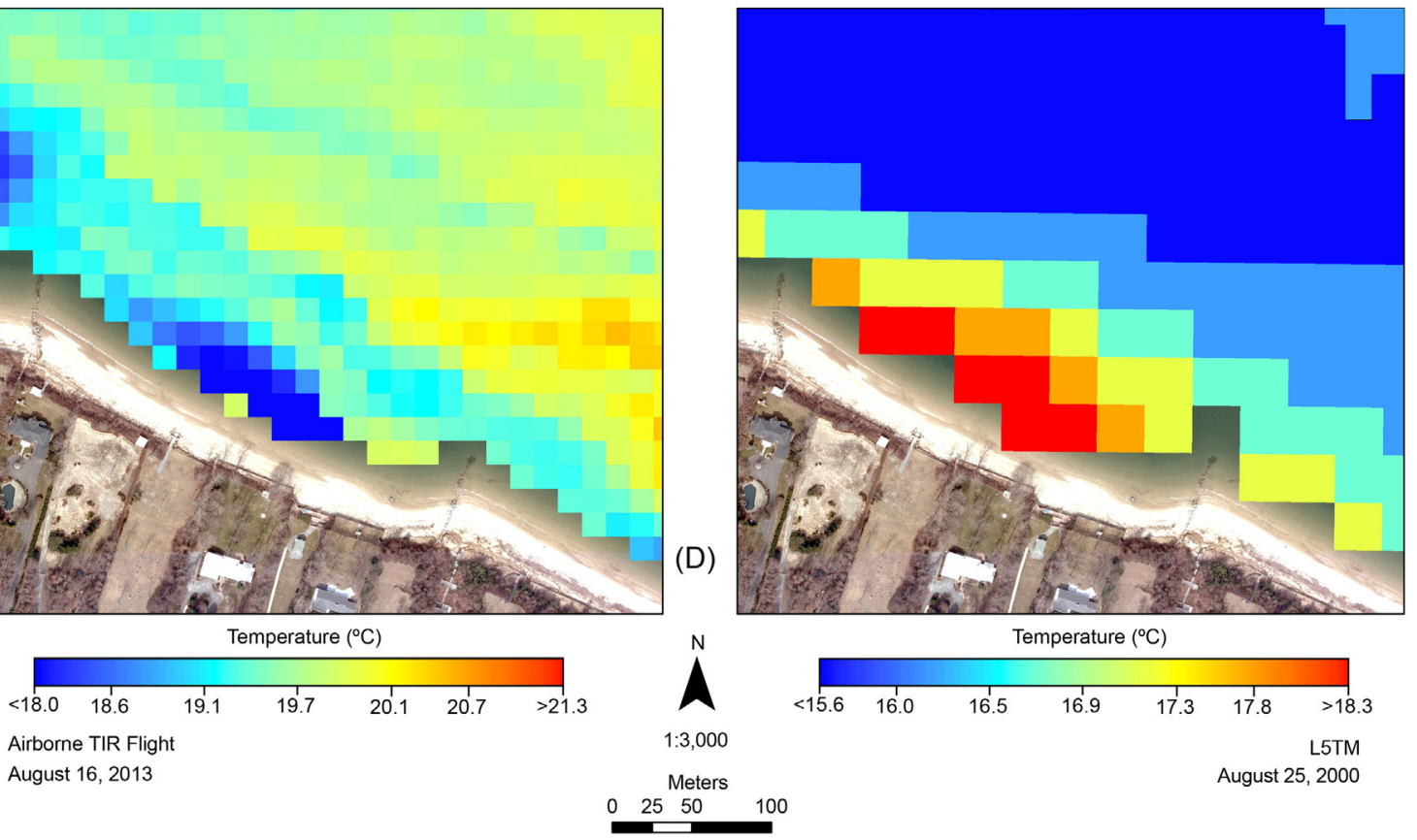

Airborne TIR Flight

$1: 3,000$

August 16, 2013

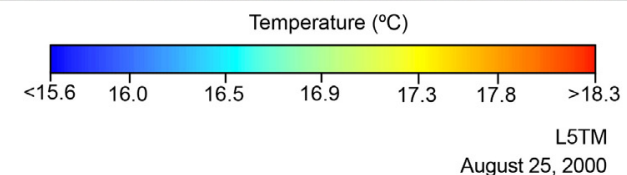

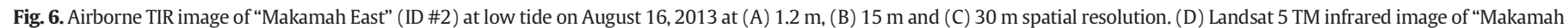
East" at low tide on August 25, 2000 with $120 \mathrm{~m}$ resolution resampled to $60 \mathrm{~m}$ pixel size.

are useful tracers for this analysis. The SGD rate regression equation slopes for Smithtown Bay, eastern Suffolk County and Port Jefferson Harbor are $0.0006,0.0007$, and $0.0012 \mathrm{~cm} \mathrm{~d}^{-1} \mathrm{~m}^{-2}$, respectively.

Dulaiova et al. (2010) showed that total SGD (fresh plus circulated seawater) can be calculated from shoreline ${ }^{222} \mathrm{Rn}$ surveys if the area of the seepage face is known. We define the offshore extent of our seepage face in Smithtown Bay and Eastern Long Island Sound as $30 \mathrm{~m}$, based on the infrared temperature transects (Figs. 2B, 3B) and seepage meter results (Fig. 8). The lateral extent of our seepage face is taken as the halfway point in between each ${ }^{222} \mathrm{Rn}$ measurement. Total SGD estimates for Smithtown Bay, eastern Suffolk County, and Port Jefferson Harbor exhibit a positive linear relationship with TIR anomaly area (Fig. 7B). The regression slope of Port Jefferson Harbor $\left(0.1 \mathrm{~m}^{3} \mathrm{~d}^{-1} \mathrm{~m}^{-2}\right)$ is significantly less than Smithtown Bay $\left(0.3 \mathrm{~m}^{3} \mathrm{~d}^{-1} \mathrm{~m}^{-2}\right)$ and eastern Suffolk County $\left(0.3 \mathrm{~m}^{3} \mathrm{~d}^{-1} \mathrm{~m}^{-2}\right)$ because Port Jefferson Harbor is a considerably smaller body of water, permeable sediments extend no further than $23 \mathrm{~m}$ from the shoreline, and measurements were made at 200$250 \mathrm{~m}$ intervals (Young et al., 2015).

\subsection{Site inter-comparison}

Seepage meters recorded spatially and temporally variable SGD at Callahan's Beach (ID \#4; Site 1) and Long Beach (ID \#8; Site 1) during June 2014. At Callahan's Beach, SGD measured via seepage meters ranged from 5 to $47 \mathrm{~cm} \mathrm{~d}^{-1}$, with maximum values recorded approximately one hour after low tide for all four meters (Fig. 8A). Measured SGD decreased in salinity over the course of the tidal cycle, with salinity varying from 15.6 to 26.7. Pore-water $\mathrm{NO}_{3}^{-}$sampled from the seepage meters followed conservative, linear mixing between the fresh groundwater and circulated seawater endmembers (Fig. 8C). September surface-water ${ }^{222} \mathrm{Rn}$ activities varied from 2.5 to $22.2 \mathrm{~Bq} \mathrm{~m}^{-3}$ with an inverse relation to the tidal water-level elevation (Fig. 9A). SGD rates calculated from the ${ }^{222} \mathrm{Rn}$ time series ranged from 3 to $38 \mathrm{~cm} \mathrm{~d}^{-1}$ with an average seepage rate of $18 \mathrm{~cm} \mathrm{~d}^{-1}$ for the September survey (Fig. 9C). Pore-water profiles displayed an upper saline circulation cell within the intertidal zone, with persistent freshwater at depths greater than $4 \mathrm{~m}$ and ubiquitous freshwater at the high water mark (Fig. S2A). 
Table 2

${ }^{222} \mathrm{Rn}$ surface water activities and SGD estimates for all study sites along the north shore of Long Island, NY. Pore-water salinities were measured at the low tide mark of the beach using a shallow push-point piezometer. Location ID numbers correspond to Fig. 1.

\begin{tabular}{|c|c|c|c|c|c|c|}
\hline \multirow[t]{2}{*}{ Location } & \multirow[t]{2}{*}{ ID } & \multirow[t]{2}{*}{$\begin{array}{l}\text { Pore-water } \\
\text { salinity }\end{array}$} & \multirow{2}{*}{$\begin{array}{l}{ }^{222} \mathrm{Rn} \\
\mathrm{Bq} \mathrm{m}^{-3}\end{array}$} & \multirow{2}{*}{$\begin{array}{l}{ }^{222} \mathrm{Rn} \\
\text { error } \\
\mathrm{Bq} \mathrm{m}^{-3}\end{array}$} & \multirow{2}{*}{$\begin{array}{l}{ }^{222} \mathrm{Rn} \\
\mathrm{SGD} \\
\mathrm{cm} \mathrm{d}^{-1}\end{array}$} & \multirow{2}{*}{$\begin{array}{l}{ }^{222} \mathrm{Rn} \mathrm{SGD} \\
\text { error } \\
\mathrm{cm} \mathrm{d}^{-1}\end{array}$} \\
\hline & & & & & & \\
\hline \multicolumn{7}{|l|}{ Smithtown Bay - Site 1} \\
\hline Makamah West & 1 & 26 & 37.7 & 18.4 & 3.2 & 0.8 \\
\hline Makamah East & 2 & 27 & 53.5 & 21.9 & 4.4 & 1.0 \\
\hline Callahan's Beach West & 3 & 23 & 44.3 & 19.8 & 6.1 & 1.2 \\
\hline Callahan's Beach East & 4 & 14 & 23.7 & 15.2 & 5.0 & 1.1 \\
\hline Sunken Meadow Bluffs & 5 & 27 & 22.2 & 14.9 & 2.1 & 0.9 \\
\hline Eastern Short Beach & 6 & 24 & 21.1 & 14.7 & 5.6 & 2.0 \\
\hline Long Beach Bluffs & 7 & 27 & 28.4 & 16.3 & 16.2 & 3.1 \\
\hline Long Beach & 8 & 29 & 24.0 & 14.2 & 2.0 & 0.9 \\
\hline West Meadow Beach & 9 & 26 & 17.8 & 13.7 & 1.5 & 0.8 \\
\hline Crane Neck & 10 & 29 & 8.6 & 10.5 & 0.9 & 0.8 \\
\hline \multicolumn{7}{|c|}{ Port Jefferson Harbor - Site 2} \\
\hline Van Brunt Manor Road & 12 & 35.6 & 352 & 272 & 6.1 & 2.3 \\
\hline Centennial Park & 13 & 26.7 & 420 & 300 & 7.4 & 2.6 \\
\hline Saints Orchard Road & 14 & 26.7 & 150 & 213 & 13.0 & 6.4 \\
\hline Molts Hollow Road & 15 & 26.2 & 369 & 291 & 5.5 & 2.3 \\
\hline Anchorage Road & 16 & 32.3 & 587 & 342 & 2.3 & 1.8 \\
\hline McAllister Park & 17 & 34.4 & 183 & 198 & 1.6 & 1.6 \\
\hline \multicolumn{7}{|c|}{ Eastern Suffolk County - Site 3} \\
\hline Miller Place & 18 & 23.9 & 22.2 & 13.7 & 8.2 & 3.4 \\
\hline Wading River West & 19 & 21.6 & 15.7 & 12.0 & 4.7 & 2.6 \\
\hline Wading River East & 20 & 28.4 & 18.3 & 12.7 & 7.2 & 2.8 \\
\hline Beach Way Marsh & 21 & 28.7 & 27.4 & 14.9 & 9.5 & 3.2 \\
\hline Baiting Hollow & 22 & 21.2 & 22.2 & 13.7 & 7.1 & 2.6 \\
\hline Northville & 23 & 19.0 & 15.6 & 12.0 & 5.0 & 2.2 \\
\hline Mattituck Inlet & 24 & 29.3 & 11.7 & 10.8 & 1.4 & 1.0 \\
\hline
\end{tabular}

At Long Beach, SGD measured from seepage meters ranged from 5 to $28 \mathrm{~cm} \mathrm{~d}^{-1}$ with maximum values recorded at low tide for all four meters (Fig. 8B). Seepage meter S4, placed $3 \mathrm{~m}$ from S1, recorded substantially higher flow rates over the entire sampling period in comparison to S1. Meters S2 and S3, placed further offshore, recorded higher flow rates than the meters closest to the shoreline, suggesting that measurable flow heterogeneity exists at Long Beach. Salinity varied from 25.6 to 27.1 between the four meters and did not exhibit any relationship with $\mathrm{NO}_{3}^{-}$(Fig. 8C). High salinity pore-water at Long Beach suggests that SGD is composed of circulated seawater. Surface-water ${ }^{222} \mathrm{Rn}$ activities ranged from 1.5 to $57.7 \mathrm{~Bq} \mathrm{~m}^{-3}$ and showed temporal variability with an inverse relationship with tidal water-level elevation (Fig. 9B). ${ }^{222} \mathrm{Rn}$ time series SGD rates ranged from 1 to $27 \mathrm{~cm} \mathrm{~d}^{-1}$ with an average rate of $8 \mathrm{~cm} \mathrm{~d}^{-1}$ for the September survey (Fig. 9D). Pore-water profiles revealed a shallow freshwater lens from 1 to $2 \mathrm{~m}$ depth at the high water mark, followed by a rapid increase in salinity with depth. High salinity pore-water was observed along all depths within the intertidal zone. At the high water mark, brackish pore-water was present at $6 \mathrm{~m}$ depth, suggesting that Long Beach has potential for regional freshwater discharge (Fig. S2B).
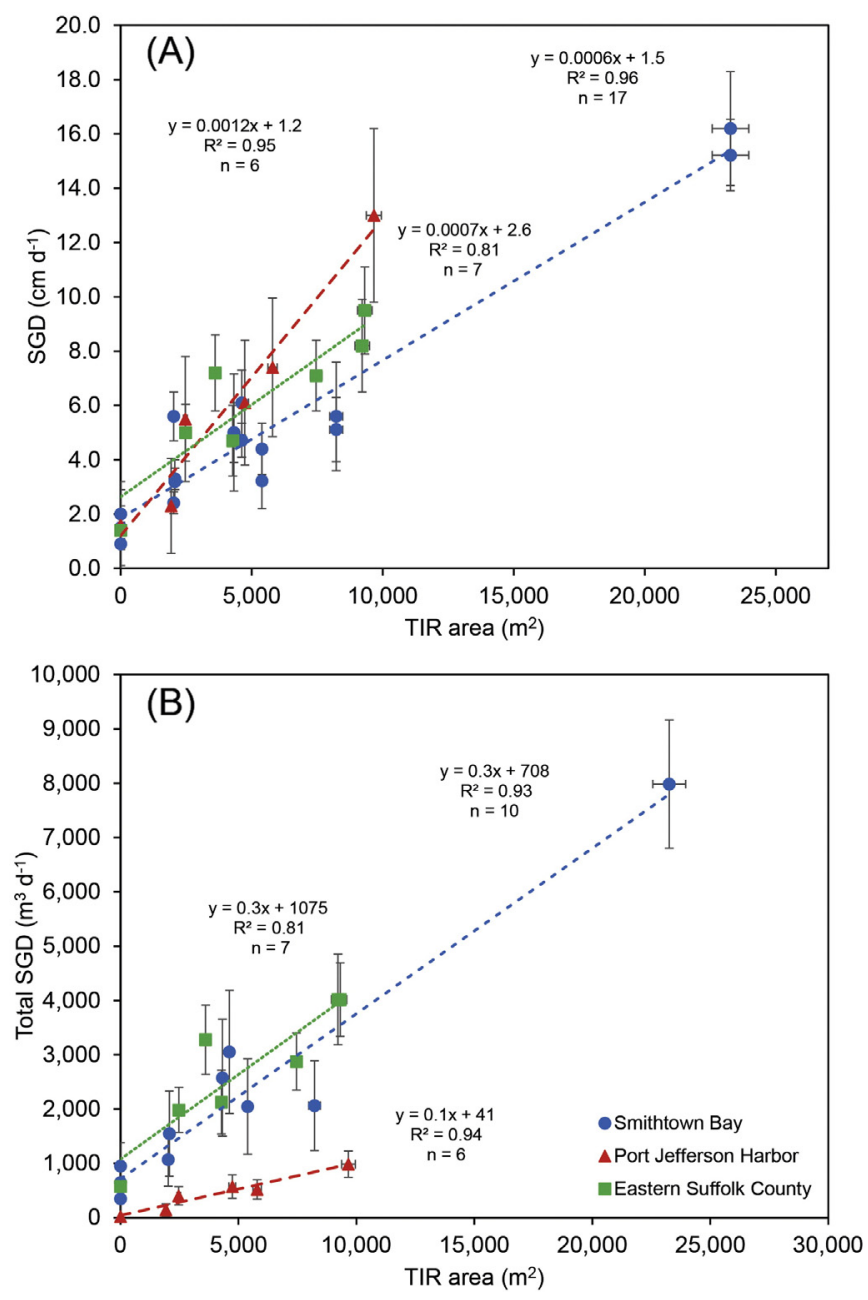

Fig. 7. (A) Estimated SGD rate, calculated from shoreline radionuclide surveys ( ${ }^{224} \mathrm{Ra}$ and ${ }^{222} \mathrm{Rn}$ ), vs. TIR anomaly area. (B) Total SGD (fresh + circulated), calculated from shoreline ${ }^{222} \mathrm{Rn}$ surveys, vs. TIR anomaly area. Only ${ }^{222} \mathrm{Rn}$ derived SGD values are reported, as the shoreline ${ }^{222} \mathrm{Rn}$ surveys provided a larger, spatially integrated measurement in comparison with ${ }^{224} \mathrm{Ra}$.

\section{Discussion}

\subsection{Fresh vs. Saline SGD}

\subsubsection{Identification of fresh SGD}

Results from the seepage meter measurements and the ${ }^{222} \mathrm{Rn}$ time series suggests that SGD at Callahan's Beach, within a large diffuse TIR anomaly (Fig. 3), was a site of mixed fresh and circulated seawater SGD. In contrast, pore-water salinity measurements suggest that SGD at Long Beach was composed of circulated seawater only. Despite the

Table 3

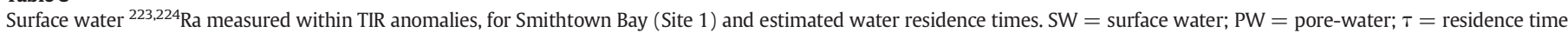
(days).

\begin{tabular}{|c|c|c|c|c|c|c|c|c|c|}
\hline \multirow[t]{2}{*}{ Location } & \multirow[t]{2}{*}{ ID } & \multirow{2}{*}{$\frac{{ }^{224} \mathrm{Ra}}{\mathrm{Bq} \mathrm{m^{-3 }}}$} & \multirow{2}{*}{$\frac{{ }^{224} \mathrm{Ra} \text { error }}{\mathrm{Bq} \mathrm{m}^{-3}}$} & \multirow{2}{*}{$\frac{{ }^{223} \mathrm{Ra}}{\mathrm{Bq} \mathrm{m}^{-3}}$} & \multirow{2}{*}{$\frac{{ }^{223} \text { Ra error }}{\mathrm{Bq} \mathrm{m}^{-3}}$} & \multirow{2}{*}{$\frac{\mathrm{SW} \tau}{\mathrm{d}}$} & \multirow{2}{*}{$\frac{\mathrm{PW} \tau}{\mathrm{d}}$} & \multirow{2}{*}{$\frac{{ }^{224} \mathrm{Ra} \text { SGD }}{\mathrm{cm} \mathrm{d}^{-1}}$} & \multirow{2}{*}{$\frac{{ }^{224} \text { Ra SGD error }}{\mathrm{cm} \mathrm{d}^{-1}}$} \\
\hline & & & & & & & & & \\
\hline Makamah West & 1 & 5.10 & 0.27 & 0.33 & 0.02 & 2.2 & 1.3 & 3.3 & 0.4 \\
\hline Makamah East & 2 & 5.08 & 0.13 & 0.24 & 0.01 & 2.0 & 1.6 & 3.2 & 1.0 \\
\hline Callahan's Beach West & 3 & 7.04 & 0.19 & 0.41 & 0.01 & 1.8 & 2.1 & 4.7 & 0.6 \\
\hline Callahan's Beach East & 4 & 6.43 & 0.17 & 0.47 & 0.01 & 2.6 & 1.0 & 5.0 & 0.7 \\
\hline Sunken Meadow Bluffs & 5 & 4.03 & 0.10 & 0.30 & 0.01 & 2.4 & 1.1 & 2.4 & 0.4 \\
\hline Eastern Short Beach & 6 & 3.81 & 0.10 & 0.23 & 0.01 & 1.4 & 0.7 & 5.1 & 1.2 \\
\hline Long Beach Bluffs & 7 & 16.17 & 0.42 & 1.48 & 0.04 & 2.1 & 1.4 & 15.2 & 1.3 \\
\hline
\end{tabular}



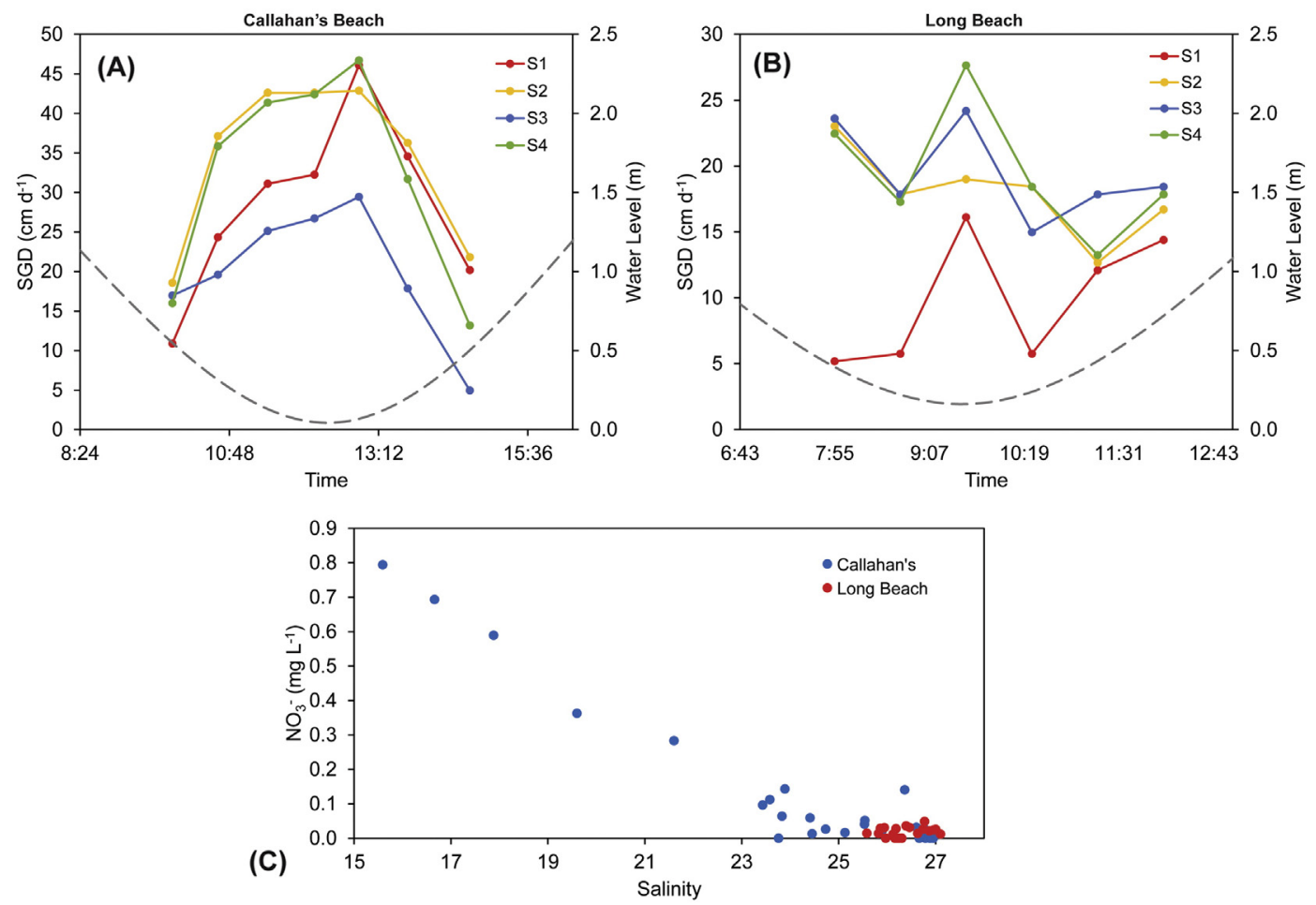

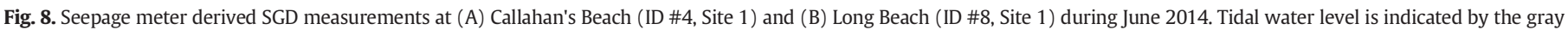
dashed line. (C) SGD salinity vs $\mathrm{NO}_{3}^{-}$from the seepage meter sampling campaign for Callahan's Beach and Long Beach.

absence of any substantial freshwater discharge at Long Beach (as indicated by the seepage meters), seepage rates between the two sites were similar in magnitude (Figs. 8, 9). We have identified a positive, linear relationship between SGD magnitude and the surface areal extent of a TIR anomaly (Section 3.3; Fig. 7). Based on the measured SGD fluxes from the three study sites, SGD must exceed $2.1 \mathrm{~cm} \mathrm{~d}^{-1}$ in order to produce a TIR anomaly (Tables $2 \& 3$ ). From the ${ }^{222} \mathrm{Rn}$ time series and seepage meter data, we would expect a coastal TIR anomaly to occur at Long Beach, however, no such anomaly was observed (Fig. 5). The absence of a TIR anomaly in the presence of significant SGD suggests that pore- water salinity is tightly coupled to the magnitude of SGD flux and that SGD sourced from circulated seawater processes does not have a sufficiently long residence time within the subterranean estuary (STE) to be thermally contrasted with respect to the ambient seawater from which it was derived.

TIR remote sensing can qualitatively identify mixed fresh and circulated seawater SGD and in this study was unable to identify areas composed exclusively of circulated seawater SGD. This is demonstrated by shallow pore-water salinity at each location (Tables 2 \& 3), in situ surface-water temperature/salinity data from Centennial Park (ID \#13,
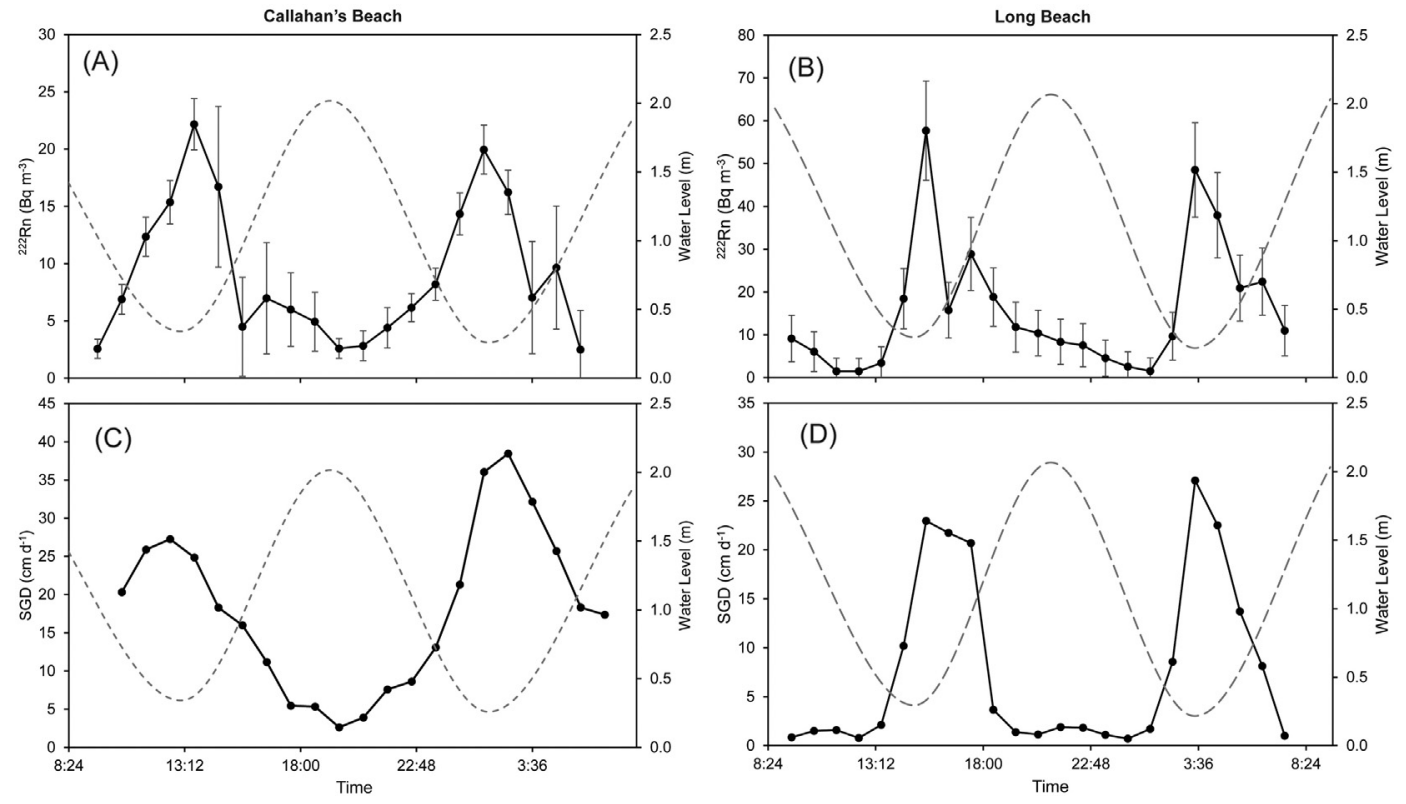

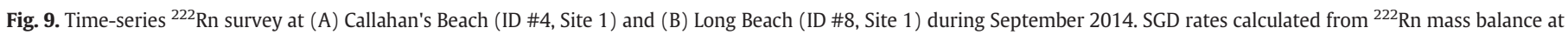
(C) Callahan's Beach and (D) Long Beach. 
Site 2; Fig. 4) and by the seepage meter results from the localized site inter-comparison experiments (Section 3.4). The three sampled locations that were unable to be resolved by TIR imaging in Smithtown Bay have pore-water salinities between 26 and 29. In comparison, the seven locations sampled within a TIR anomaly have shallow porewater salinities that vary from 14 to 27. For the eastern Suffolk County survey, shallow pore-water salinity within TIR anomaly areas varied from 19 to 28.7, with pore-water salinity in excess of 29 outside of TIR anomalies. While pore-water data is limited, these results suggest that the observed TIR anomalies were composed of a mix between freshwater and circulated seawater.

Fresh SGD has a substantial thermal contrast with ambient surfacewaters because the fresh fraction of SGD reflects the mean annual groundwater temperature (Anderson, 2005). Circulated sea-water SGD is likely to have less thermal contrast with surface-waters on short residence time scales within the beach face (Befus, Cardenas, Erler, Santos, \& Eyre, 2013). Pore-water residence times for the sites where SGD was composed of circulated seawater were likely not long enough to cool the pore-water within the beach face relative to the ambient surface-waters ( mean $=1.3 \pm 0.4 \mathrm{~d}$, Table 3 ). Saline SGD derived from seasonal oscillations of the water table (Michael et al., 2005), density-driven circulation (Robinson et al., 2007) and flow across permeable barriers (Santos et al., 2012) are the only mechanisms that could support a sufficiently long residence time (greater than weeks) to permit thermal contrast with sea-water. Although TIR imagery is unable to differentiate between saline SGD and no SGD (which we do not consider based on the excess radionuclide activities) we surmise that the absence of a TIR anomaly provides useful information regarding the mechanisms driving SGD and possibly solute transport.

\subsubsection{Fresh fraction estimates}

Airborne TIR imagery can create accurate sea surface temperature maps, which can be used as a proxy for estimating surface-water nutrient concentrations if there is an established relationship between surface-water temperature, salinity and the nutrient of interest (Johnson et al., 2008). A relationship between surface-water temperature and salinity is difficult to establish in heterogeneous, diffuse flow systems where surface-water salinity gradients are minimal and river inputs exist. Furthermore, complex biogeochemical reactions that take place in the STE just prior to discharge may alter the final nutrient species and overall concentration (Erler et al., 2014), which in turn complicates mapping nutrients via TIR imagery. In eutrophic areas where there is rapid biological uptake and utilization of surface-water nutrients, TIR nutrient mapping of surface-waters is not possible. While we cannot map surface-water nutrients via TIR imagery in eutrophic environments, we can use the fresh fraction of SGD to calculate more accurate SGD nutrient loads as long as pore-water nutrient endmembers have been accurately quantified.

If TIR anomalies can be demonstrated to represent a mixture of fresh and circulated seawater SGD, as they have been here, then the cumulative area of TIR anomalies can be used to represent the spatial extent of a region's diffuse fresh seepage face for improved fresh/saline SGD mass balance estimates. Conservative mixing between nitrate rich, fresh SGD and nitrate poor, saline SGD was measured by the seepage meter sampling campaign at Callahan's Beach (Fig. 8C). A substantial nitrate load was being supplied by SGD, despite the absence of any substantial dissolved inorganic nitrate in the overlying surface-waters.

Port Jefferson Harbor had a total TIR anomaly area of $24,540 \mathrm{~m}^{2}$ at low tide during September 2014 (Table 1). The average ${ }^{222} \mathrm{Rn}$-derived specific discharge for the identified TIR regions was $6.9 \mathrm{~cm} \mathrm{~d}^{-1}$. Distributed over the area of the TIR anomaly, this corresponds to $1680 \mathrm{~m}^{3} \mathrm{~d}^{-1}$ of fresh SGD, or approximately $11 \%$ of the total SGD estimate, which is in agreement with estimates from other locations on Long Island (Beck et al., 2008). Fresh fraction SGD estimates following Dulaiova et al. (2010) are estimated to be $8 \%$ of the total SGD for Port Jefferson Harbor. Young et al. (2015) classify SGD into Port Jefferson Harbor into three types of nutrient modes according to sub-watershed boundaries: (1) high, fresh, nutrient-rich SGD in the southern watershed; (2) moderate SGD with moderate nutrients along the eastern watershed and (3) low, nutrient poor circulated SGD in the northern and western watersheds. Qualitatively, the TIR data from this study supports the conclusions of Young et al. (2015). There were no TIR anomalies identified adjacent to the northern watershed. Only one TIR anomaly was identified along the western watershed, which corresponded to the western shoreline segment with the greatest total SGD (ID \#12). The agreement between observations taken in 2012 and ours taken in 2014 suggest that the spatial patterns of fresh SGD into Port Jefferson Harbor are consistent over several years.

\subsection{Technique limitations}

TIR quantification of diffuse SGD provides conservative SGD estimates. If the water column is stratified, as it often is during the summer in Smithtown Bay and Long Island Sound (Garcia-Orellana et al., 2014), then cold water inputs from SGD may not reach the water's surface. This limits our methodology to resolving nearshore temperature differences and likely cannot capture offshore seepage (i.e. submarine springs) in deeper environments. Care should be taken to plan overflights during optimal viewing conditions. The time of year and day should be accounted for to maximize thermal contrast and to reduce effects from solar radiation, shadows, clouds and any other environmental variables that may influence sea surface temperature (Duarte et al., 2006).

When comparing surveys from different locations and times, as we do here, one must be aware of the influence of differences in tidal stages and the effects of solar heating on the water column. Considering that each flight was conducted at different times (of the day and year), one might expect there to be a significant difference in $\Delta \mathrm{T}$ and the $\Delta \mathrm{T}$ vs TIR anomaly area $\left({ }^{\circ} \mathrm{C} \mathrm{m}^{-2}\right)$ slope between each flight. While we do not observe any significant difference between each flights $\Delta \mathrm{T}$ vs TIR anomaly area slope (Section 3.1.1; Fig. S1), we acknowledge that differences in solar heating of the water column, particularly for the Smithtown Bay flight that was conducted later in the day, may control both $\Delta \mathrm{T}$ and the TIR anomaly areas (e.g. Banks et al., 1996), resulting in poor correlation coefficients. TIR flights performed later in the day may diminish the thermal contrast between SGD and surface waters, although this would likely result in conservatively defined TIR anomaly areas. SGD varies with time on tidal and seasonal scales (Michael et al., 2005); SGD should be measured during the same tidal stage and season to reduce temporal uncertainties. Overflights should be performed during low wind conditions to reduce thermal interference from mixing, waves and upwelling processes.

Airborne TIR remote sensing can be a powerful technique for identifying SGD even from oblique imagery (Duarte et al., 2006). As long as images are taken at approximately the same altitude and angle, any spatial error due to obliquity will be relative between images and regions, thus the relative error in area from one location to the next should be equal. Studies that require a precise, low uncertainty should quantify SGD directly.

\subsection{Geologic controls on TIR signal}

The slope of a discharge area vs SGD regression line will likely vary with varying regional hydrogeologic conditions (Kelly et al., 2013), such as aquifer porosity, permeability, hydraulic conductivity and hydraulic gradient. For a fractured bedrock aquifer (Bokuniewicz et al., 2008; Wilson \& Rocha, 2012) or a karstic aquifer (Mejias et al., 2012), discharge can occur through preferential flow paths, and as a result, may be significantly greater than sandy outwash beaches subject to diffuse SGD. Geologic controls on SGD, including influence by the hydraulic gradient, may control the slopes of our regression equations. A total SGD $\left(\mathrm{m}^{3} \mathrm{~d}^{-1}\right)$ vs TIR area $\left(\mathrm{m}^{2}\right)$ slope of $0.5 \mathrm{~m}^{3} \mathrm{~d}^{-1} \mathrm{~m}^{-2}$ was calculated for a basaltic environment in Hawai'i (Kelly et al., 2013). Danielescu et al. 
Table 4

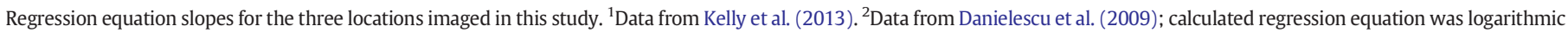
and represented stream discharge rather than SGD.

\begin{tabular}{|c|c|c|c|}
\hline \multirow[t]{2}{*}{ Location } & Specific Q vs. area slope & Total Q vs. area slope & \multirow[t]{2}{*}{ Aquifer type } \\
\hline & $\mathrm{cm} \mathrm{d}^{-1} \mathrm{~m}^{-2}$ & $\mathrm{~m}^{3} \mathrm{~d}^{-1} \mathrm{~m}^{-2}$ & \\
\hline Smithtown Bay, NY & 0.0006 & 0.3 & \multirow[t]{3}{*}{ Glacial outwash deposits } \\
\hline Eastern Long Island, NY & 0.0007 & 0.3 & \\
\hline Port Jefferson Harbor, NY & 0.0012 & 0.1 & \\
\hline Pearl Harbor, Hawaii ${ }^{1}$ & $\mathrm{n} / \mathrm{a}$ & 0.5 & Volcanic basalts \\
\hline Prince Edward Island, Canada ${ }^{2}$ & $\mathrm{n} / \mathrm{a}$ & 52 & Glacial till \& highly fractured sandstone \\
\hline
\end{tabular}

(2009) calculated a stream discharge vs TIR area regression slope of $52 \mathrm{~m}^{3} \mathrm{~d}^{-1} \mathrm{~m}^{-2}$ for a highly fractured sandstone aquifer. In comparison, we calculated total SGD regression slopes of $0.1,0.3$ and $0.3 \mathrm{~m}^{3} \mathrm{~d}^{-1} \mathrm{~m}^{-2}$ for a sandy, coastal plain aquifer (Table 4).

The SGD rate (specific discharge) regression equation (Fig. 7A) does not have any scaling biases and can thus be used to compare regions of varying size (Table 4). The slope for Port Jefferson Harbor $\left(0.0012 \mathrm{~cm} \mathrm{~d}^{-1} \mathrm{~m}^{-2}\right)$ is 2 and 1.7 times greater than the slopes calculated for Smithtown Bay $\left(0.0006 \mathrm{~cm} \mathrm{~d}^{-1} \mathrm{~m}^{-2}\right)$ and eastern Suffolk County $\left(0.0007 \mathrm{~cm} \mathrm{~d}^{-1} \mathrm{~m}^{-2}\right)$. A greater SGD rate regression slope for Port Jefferson Harbor is indicative of concentrated groundwater discharge in semi-enclosed coastal embayments (Cherkauer \& McKereghan, 1991; Durand, 2014) in comparison with straight beach face environments. The three regression equations calculated in this study highlight the importance of regionally characterizing SGD in different hydrogeologic and geomorphologic environments. In the absence of freshwater SGD, the y-intercept of an SGD rate regression line should represent the rate of tidally modulated, saline SGD. Even with zero freshwater discharge, a sandy, sloped permeable beach should be subject to circulated SGD via wave and tidal pumping (Santos et al., 2012).

Along the southern shore of Long Island, seepage rates were found to be reduced under the presence of local impermeable sediments (Bokuniewicz, 1980). Seepage variability has been linked to sediment heterogeneity in which low permeability infill deposits inhibited discharge of fresh groundwater along the shoreline, funneling freshwater further offshore (Russoniello et al., 2013). Geologic faults were spatially correlated with TIR anomalies and excess ${ }^{222} \mathrm{Rn}$ activities along the coast of Ireland, where geologic faults hydraulically enhanced SGD input to the coast (Wilson \& Rocha, 2012). As with these locations, the TIR area of diffuse SGD along the north shore of Long Island may be controlled, in part, by coastal geology. While we cannot obtain subsurface information from TIR imagery, we acknowledge that the presence of subsurface structures (i.e. clay lenses) may impede local discharge and thus limit the production of a coastal TIR anomaly. Thus, when drawing conclusions from TIR imagery, in situ measurements are required to distinguish between SGD inhibited sites and saline SGD. Visible light imagery and bathymetry data sets can be used in a GIS to confirm that water depth is not controlling the observed TIR signal. An example of surficial geologic controls on a TIR signal is illustrated in Fig. 2A, where a large, tidally exposed glacial erratic has masked a portion of the cool nearshore TIR anomaly.

Table 5

Application of TIR regression equations to previously identified TIR imagery. Stony Brook Harbor TIR data was collected from a preliminary flight in February 2013 and SGD is calculated from the Port Jefferson Harbor regression equation. Wading River TIR data was taken during June 1969 (Pluhowski, 1972); SGD is calculated from the eastern Suffolk County regression equation.

\begin{tabular}{|c|c|c|c|}
\hline \multirow[t]{2}{*}{ Location } & \multirow[t]{2}{*}{ ID } & TIR area & Estimated SGD \\
\hline & & $\mathrm{m}^{2}$ & $\mathrm{~cm} \mathrm{~d}^{-1}$ \\
\hline Western Stony Brook Harbor & 11 & 11,400 & 15 \\
\hline Wading River West & 19 & 3800 & 5 \\
\hline Wading River East & 20 & 10,700 & 10 \\
\hline
\end{tabular}

\subsection{Application of regression equation to estimate $S G D$}

A preliminary airborne TIR survey identified an extensive, diffuse TIR anomaly along the western shoreline of Stony Brook Harbor, NY in February 2013. Delineating the area of the identified temperature anomaly, we calculate a TIR area of $11,400 \mathrm{~m}^{2}$. Stony Brook Harbor is an embayment of similar size and hydrogeology to Port Jefferson Harbor, both exchanging waters with Long Island Sound with semidiurnal tides $(\sim 2.0 \mathrm{~m})$. Application of the TIR regression equation from Port Jefferson Harbor yields an SGD rate of approximately $15 \mathrm{~cm} \mathrm{~d}^{-1}$ (Table 5). Previous work in Stony Brook Harbor along the western shoreline measured average SGD rates via ultrasonic and manual seepage meters of 29.8 and $23 \mathrm{~cm} \mathrm{~d}^{-1}$ (Durand, 2014). Radionuclides and thermal imaging are designed to be used as larger scale, spatially integrated measurements. Our remotely estimated seepage rate for Western Stony Brook Harbor likely reflects an average seepage rate, whereas the seepage meter estimates highlight small scale aquifer heterogeneities (Bokuniewicz et al., 2008; Michael et al., 2003).

Thermal infrared imagery acquired on 17 June 1969 over Wading River, NY (Pluhowski, 1972) found two non-point source SGD anomalies emanating into Long Island Sound. We estimate TIR areas of $3800 \mathrm{~m}^{2}$ and $10,700 \mathrm{~m}^{2}$ for the two distinct diffuse seepage zones (Table 5). Wading River is located within our eastern Suffolk County site (Site 3, Fig. 1). Using our eastern Suffolk County regression equation, we calculate seepage rates of 5 and $10 \mathrm{~cm} \mathrm{~d}^{-1}$ for Wading River 1 and 2 during 1969. These estimates fall well within the range of estimates calculated from our eastern Suffolk County ${ }^{222} \mathrm{Rn}$ survey, where we measured 4.7 and $7.2 \mathrm{~cm} \mathrm{~d}^{-1}$ at the same locations in September 2014. Application of our regression equation highlights the versatility of remote sensing for the assessment of SGD over large time scales and the capability to upscale local measurements to a regional basis.

\section{Conclusions}

Airborne thermal infrared remote sensing can be used as a quantitative tool for estimating non-point source diffuse submarine groundwater discharge (SGD) by delineating the surface area of a thermal infrared (TIR) anomaly. Discharge estimates determined from ${ }^{224} \mathrm{Ra}$ and ${ }^{222} \mathrm{Rn}$ coastal surveys positively correlate with the areal extent of cool nearshore TIR anomalies for several locations along the north shore of Long Island, NY. At its current spatial resolution, Landsat TIR data is inadequate for properly resolving diffuse SGD along Long Island.

SGD was characterized in greater detail at two thermally contrasting field sites using manual seepage meters and ${ }^{222} \mathrm{Rn}$ time series measurements. Results indicate that the site within a large, diffuse TIR anomaly was composed of a mixture between fresh and circulated seawater SGD whereas the second site, where no TIR anomaly was observed, was composed of circulated seawater SGD only. Despite the absence of significant freshwater discharge at the second site, SGD rates between the two sites were comparable. Results suggest that TIR imagery identifies locations of a mixture between fresh and circulated seawater SGD rather than circulated seawater SGD alone, and is a useful tool for this purpose. As a result, the cumulative thermal area of a region can be used 
as an approximation for the spatial extent of the diffuse fresh seepage face to better calculate the fresh fraction of SGD in diffuse environments. This technique can be applied to any region where there is an adequate temperature difference between discharging pore-waters and ambient surface-waters. Application of this technique can allow researchers to remotely perform time-series estimates of SGD fluxes at previously sampled locations, as we demonstrate with TIR data from Wading River, NY. Regression equations developed for different geologic environments may be applied to regions where intensive field sampling may not be practical or possible.

\section{Acknowledgments}

This work was supported by NASA Headquarters under the NASA Earth and Space Science Fellowship Program - Grant 13-EARTH13F175. Additional funding was provided by New York Sea Grant project R/CMC-12. The authors would like to thank David Bowman, Josephine Durand, Christina Heilbrun and John Rapaglia for their assistance with laboratory and field work, as well as the helpful comments made by three anonymous reviewers.

\section{Appendix A. Supplementary data}

Supplementary data to this article can be found online at http://dx. doi.org/10.1016/j.rse.2015.10.010.

\section{References}

Anderson, M. (2005). Heat as a ground water tracer. Ground Water, 43, 951-968. Banks, W., Paylor, R., \& Hughes, W. (1996). Using thermal-infrared imagery to delineate ground-water discharge. Ground Water, 34, 434-443.

Beck, A., Rapaglia, J., Cochran, J., \& Bokuniewicz, H. (2007b). Radium mass-balance in Jamaica bay, NY: Evidence for a substantial flux of submarine groundwater. Marine Chemistry, 106, 419-441.

Beck, A., Rapaglia, J., Cochran, J., Bokuniewicz, H., \& Yang, S. (2008). Submarine groundwater discharge to great south bay, NY, estimated using Ra isotopes. Marine Chemistry, 109, 279-291.

Beck, A., Tsukamoto, Y., Tovar-Sanchez, A., Huerta-Diaz, M., Bokuniewicz, H., \& SanudoWilhelmy, S. (2007a). Importance of geochemical transformations in determining submarine groundwater discharge-derived trace metal and nutrient fluxes. Applied Geochemistry, 22, 477-490.

Becker, M. W. (2006). Potential for satellite remote sensing of ground water. Ground Water, 44, 306-318.

Befus, K., Cardenas, M., Erler, D., Santos, I., \& Eyre, B. (2013). Heat transport dynamics at a sandy intertidal zone. Water Resources Research, 49, 3770-3786.

Bokuniewicz, H. (1980). Groundwater seepage into Great South Bay, New York. Estuarine and Coastal Marine Science, 10, 437-444.

Bokuniewicz, H., \& Pavlik, B. (1990). Groundwater seepage along a barrier-island. Biogeochemistry, 10, 257-276.

Bokuniewicz, H., Cochran, J. K., Daniel, J. W. R., Garcia-Orellana, J., Rodellas, V., \& Heilbrun, C. (2015). The intertidal subterranean estuary in Long Island Sound (NY). Journal of Marine Research (in press).

Bokuniewicz, H., Pollock, M., Blum, J., \& Wilson, R. (2004). Submarine ground water discharge and salt penetration across the sea floor. Ground Water, 42, 983-989.

Bokuniewicz, H., Taniguchi, M., Ishitoibi, T., Charette, M., Allen, M., \& Kontar, E. (2008). Direct measurements of submarine groundwater discharge (SGD) over a fractured rock aquifer in Flamengo Bay Brazil. Estuarine, Coastal and Shelf Science, 76, 466-472.

Burnett, W., \& Dulaiova, H. (2003). Estimating the dynamics of groundwater input into the coastal zone via continuous radon-222 measurements. Journal of Environmental Radioactivity, 69, 21-35.

Burnett, W., Aggarwal, P., Aureli, A., Bokuniewicz, H., Cable, J., Charette, M., ... Turner, J. (2006). Quantifying submarine groundwater discharge in the coastal zone via multiple methods. Science of the Total Environment, 367, 498-543.

Burnett, W., Santos, I., Weinstein, Y., Swarzenski, P., \& Herut, B. (2007). Remaining uncertainties in the use of Rn-222 as a quantitative tracer of submarine groundwater discharge. In W.S.e. al. (Ed.) (pp. 109-118): IAHS Publ.

Buxton, H., \& Modica, E. (1992). Patterns and rates of groundwater flow on Long Island, New York. Ground Water, 30, 857-866.

Cherkauer, D.S., \& McKereghan, P.F. (1991). Groundwater discharge to lakes - focusing in embayments. Ground Water, 29, 72-80.

Cyronak, T., Santos, I.R., Erler, D.V., Maher, D.M., \& Eyre, B.D. (2014). Drivers of pCO $\mathrm{p}_{2}$ variability in two contrasting coral reef lagoons: The influence of submarine groundwater discharge. Global Biogeochemical Cycles, 28, 398-414.

Danielescu, S., MacQuarrie, K., \& Faux, R. (2009). The integration of thermal infrared imaging, discharge measurements and numerical simulation to quantify the relative contributions of freshwater inflows to small estuaries in Atlantic Canada. Hydrological Processes, 23, 2847-2859.
Duarte, T., Hemond, H., Frankel, D., \& Frankel, S. (2006). Assessment of submarine groundwater discharge by handheld aerial infrared imagery: Case study of Kaloko fishpond and bay, Hawai'i. Limnology and Oceanography: Methods, 4, 227-236.

Dulaiova, H., Burnett, W., Chanton, J., Moore, W., Bokuniewicz, H., Charette, M., \& Sholkovitz, E. (2006). Assessment of groundwater discharges into West Neck Bay, New York, via natural tracers. Continental Shelf Research, 26, 1971-1983.

Dulaiova, H., Camilli, R., Henderson, P., \& Charette, M. (2010). Coupled radon, methane and nitrate sensors for large-scale assessment of groundwater discharge and nonpoint source pollution to coastal waters. Journal of Environmental Radioactivity, 101, 553-563.

Dulaiova, H., Peterson, R., Burnett, W., \& Lane-Smith, D. (2005). A multi-detector continuous monitor for assessment of Rn-222 in the coastal ocean. Journal of Radioanalytical and Nuclear Chemistry, 263, 361-365.

Durand, J.M.K. (2014). Characterization of the spatial and temporal variations of submarine groundwater discharge using electrical resistivity and seepage measurements. (PhD Dissertation) Geosciences (pp. 183). Stony Brook University.

Erler, D., Santos, I., Zhang, Y., Tait, D., Befus, K., Hidden, A.A., ... Eyre, B. (2014). Nitrogen transformations within a tropical subterranean estuary. Marine Chemistry, 164, 38-47.

Franke, O.L., \& McClymonds, N.E. (1972). Summary of the hydrologic situation on Long Island, New York, as a guide to water-management alternatives. In U.S.G.S.P. Paper (Ed.) (p. 59)

Garcia-Orellana, J., Cochran, J.K. Bokuniewicz, H. Daniel, JW.R. Rodellas, V., \& Heilbrun, C. (2014). Evaluation of ${ }^{224} \mathrm{Ra}$ as a tracer for submarine groundwater discharge in Long Island Sound (NY). Geochimica et Cosmochimica Acta, 141, 314-330.

Garcia-Solsona, E., Garcia-Orellana, J., Masque, P., \& Dulaiova, H. (2008). Uncertainties associated with Ra-223 and Ra-224 measurements in water via a delayed coincidence counter (RaDeCC). Marine Chemistry, 109, 198-219.

Gobler, C., \& Sanudo-Wilhelmy, S. (2001). Temporal variability of groundwater seepage and brown tide blooms in a Long Island embayment. Marine Ecology Progress Series, 217, 299-309.

Gonneea, M., Mulligan, A.A., \& Charette, M. (2013). Climate-driven sea level anomalies modulate coastal groundwater dynamics and discharge. Geophysical Research Letters, 40, 2701-2706.

Johnson, A.A., Glenn, C., Burnett, W., Peterson, R., \& Lucey, P. (2008). Aerial infrared imaging reveals large nutrient-rich groundwater inputs to the ocean. Geophysical Research Letters, 35.

Kageyama, Y., Shibata, C., \& Nishida, M. (2012). Feature analysis of groundwater discharge points in coastal regions around Mt. Chokaisan using ALOS AVNIR-2 data. Electronics and Communications in Japan, 95, 1-9.

Kelly, J., Glenn, C., \& Lucey, P. (2013). High-resolution aerial infrared mapping of groundwater discharge to the coastal ocean. Limnology and Oceanography: Methods, 11, 262-277.

Kim, D., Moon, W., Kim, G., Park, S., \& Lee, H. (2011). Submarine groundwater discharge in tidal flats revealed by space-borne synthetic aperture radar. Remote Sensing of Environment, 115, 793-800

Knee, K., \& Paytan, A.A. (2011). Submarine groundwater discharge: a source of nutrients, metals, and pollutants to the coastal Ocean. Treatise on Estuarine and Coastal Science, 4, 205-233.

Kwon, E.Y., Kim, G., Primeau, F., Moore, W.S., Cho, H. -M., DeVries, T., ... Cho, Y. -K. (2014) Global estimate of submarine groundwater discharge based on an observationally constrained radium isotope model. Geophysical Research Letters, 41, 8438-8444.

Laroche, J., Nuzzi, R., Waters, R., Wyman, K., Falkowski, P., \& Wallace, D. (1997). Brown tide blooms in Long Island's coastal waters linked to interannual variability in groundwater flow. Global Change Biology, 3, 397-410.

Lee, D. (1977). Device for measuring seepage flux in lakes and estuaries. Limnology and Oceanography, 22, 140-147.

Lee, Y., Kim, G., Lim, W., \& Hwang, D. (2010). A relationship between submarine groundwater-borne nutrients traced by Ra isotopes and the intensity of dinoflagellate red-tides occurring in the southern sea of Korea. Limnology and Oceanography, 55, 1-10.

Luek, J.L., \& Beck, A.J. (2014). Radium budget of the York River estuary (VA, USA) dominated by submarine groundwater discharge with a seasonally variable groundwater end-member. Marine Chemistry, 55-65.

MacIntyre, S., Wanninkhof, R., \& Chanton, J. (1995). Trace gas exchange across the airwater interface in freshwater and coastal marine environments. Biogenic trace gases: Measuring emissions from soil and water. Methods in ecology. (pp. 52-97). Blackwell.

Mallast, U., Siebert, C., Wagner, B., Sauter, M., Gloaguen, R., Geyer, S., \& Merz, R. (2013) Localisation and temporal variability of groundwater discharge into the Dead Sea using thermal satellite data. Environmental Earth Sciences, 69, 587-603.

Martin, J., Cable, J., Jaeger, J., Hartl, K., \& Smith, C. (2006). Thermal and chemical evidence for rapid water exchange across the sediment-water interface by bioirrigation in the Indian River Lagoon, Florida. Limnology and Oceanography, $51,1332-1341$.

Mejias, M., Ballesteros, B.J., Anton-Pacheco, C., Dominguez, J.A., Garcia-Orellana, J., GarciaSolsona, E., \& Masque, P. (2012). Methodological study of submarine groundwater discharge from a karstic aquifer in the Western Mediterranean Sea. Journal of Hydrology, 464, 27-40.

Michael, H., Lubetsky, J., \& Harvey, C. (2003). Characterizing submarine groundwater discharge: a seepage meter study in Waquoit Bay, Massachusetts. Geophysical Research Letters, 30.

Michael, H., Mulligan, A.A., \& Harvey, C. (2005). Seasonal oscillations in water exchange between aquifers and the coastal ocean. Nature, 436, 1145-1148.

Moore, W. (1996). Large groundwater inputs to coastal waters revealed by Ra-226 enrichments. Nature, 380, 612-614.

Moore, W. (1999). The subterranean estuary: a reaction zone of ground water and sea water. Marine Chemistry, 65, 111-125. 
Moore, W., \& Arnold, R. (1996). Measurement of Ra-223 and Ra-224 in coastal waters using a delayed coincidence counter. Journal of Geophysical Research, Oceans, 101, $1321-1329$

Moore, W.S. (2000). Ages of continental shelf waters determined from Ra-223 and Ra224. Journal of Geophysical Research, Oceans, 105, 22117-22122.

Moore, W.S., \& Cai, P. (2013). Calibration of RaDeCC systems for ${ }^{223}$ Ra measurements. Marine Chemistry, 156, 130-137.

Mulligan, A.A., \& Charette, M. (2006). Intercomparison of submarine groundwater discharge estimates from a sandy unconfined aquifer. Journal of Hydrology, 327, 411-425.

NOAA (2007). In L.I.S.R. Center (Ed.), Bathymetric contours in meters for Long Island Sound.

Peterson, R., Burnett, W., Glenn, C., \& Johnson, A. (2009). Quantification of point-source groundwater discharges to the ocean from the shoreline of the big island, Hawaii. Limnology and Oceanography, 54, 890-904.

Peterson, R.N., Burnett, W.C., Taniguchi, M., Chen, J., Santos, I.R., \& Ishitobi, T. (2008). Radon and radium isotope assessment of submarine groundwater discharge in the yellow river delta, China. Journal of Geophysical Research, Oceans, 113.

Pluhowski, E.J. (1972). Hydrologic interpretations based on infrared imagery of Long Island, New York. Washington: U.S. Govt. Print. Off.

Portnoy, J.W., Nowicki, B.L., Roman, C.T., \& Urish, D.W. (1998). The discharge of nitratecontaminated groundwater from developed shoreline to marsh-fringed estuary. Water Resources Research, 34, 3095-3104.

Rapaglia, J., Di Sipio, E., Bokuniewicz, H., Zuppi, G.M., Zaggia, L., Galgaro, A.A., \& Beck, A.A. (2010). Groundwater connections under a barrier beach: A case study in the Venice lagoon. Continental Shelf Research, 30, 119-126.

Robinson, C., Gibbes, B., \& Li, L. (2006). Driving mechanisms for groundwater flow and salt transport in a subterranean estuary. Geophysical Research Letters, 33, 4

Robinson, C., Li, L., \& Prommer, H. (2007). Tide-induced recirculation across the aquiferocean interface. Water Resources Research, 43.

Roseen, R. (2002). Ouantifying groundwater discharge using thermal imagery and conventional groundwater exploration techniques for estimating the nitrogen loading to a meso-scale estuary. PhD Dissertation Civil engineering. (pp. 203)University of New Hampshire, 203

Russoniello, C., Fernandez, C., Bratton, J., Banaszak, J., Krantz, D., Andres, A., ... Michael, H. (2013). Geologic effects on groundwater salinity and discharge into an estuary. Journal of Hydrology, 498, 1-12.

Sadat-Noori, M., Santos, I.R., Sanders, C.J., Sanders, L.M., \& Maher, D.T. (2015). Groundwater discharge into an estuary using spatially distributed radon time series and radium isotopes. Journal of Hydrology, 528, 703-719.

Santos, I., Eyre, B., \& Huettel, M. (2012). The driving forces of porewater and groundwater flow in permeable coastal sediments: A review. Estuarine, Coastal and Shelf Science, 98, 1-15.

Santos, I.R., Beck, M., Brumsack, H.J., Maher, D.T., Dittmar, T., Waska, H., \& Schnetger, B. (2015). Porewater exchange as a driver of carbon dynamics across a terrestrialmarine transect: Insights from coupled ${ }^{222} \mathrm{Rn}$ and $p \mathrm{CO}_{2}$ observations in the German Wadden Sea. Marine Chemistry, 171, 10-20.
Sass, G.Z., Creed, I.F., Riddell, J., \& Bayley, S.E. (2013). Regional-scale mapping of groundwater discharge zones using thermal satellite imagery. Hydrological Processes.

Schubert, M., Paschke, A., Lieberman, E., \& Burnett, W. (2012). Air-water partitioning of $\mathrm{Rn}-222$ and its dependence on water temperature and Salinity. Environmental Science E Technology, 46, 3905-3911.

Scorca, M.P., Monti, J., New York (State), Department of Environmental conservation, United States, \& Environmental Protection Agency., \& Geological Survey (U.S.) (2001). Estimates of nitrogen loads entering Long Island Sound from ground water and streams on Long Island, New York, 1985-96. Coram, N.Y.: U.S. Dept. of the interior, U.S. Geological Survey.

Shaw, R.D., \& Prepas, E.E. (1989). Anomalous, short-term influx of water into seepage meters. Limnology and Oceanography, 34, 1343-1351.

Slomp, C., \& Van Cappellen, P. (2004). Nutrient inputs to the coastal ocean through submarine groundwater discharge: controls and potential impact. Journal of Hydrology, 295, 64-86.

Swarzenski, P. (2007). U/Th series radionuclides as coastal groundwater tracers. Chemical Reviews, 107, 663-674.

Tamborski, J. (2014). Seasonal variability of submarine groundwater discharge along the northshore of Long Island sond resolved using ${ }^{222} \mathrm{Rn}$. Proceedings of the 21st conference on the geology of Long Island and metropolitan New York. New York: Stony Brook University.

Taniguchi, M., Burnett, W., Cable, J., \& Turner, J. (2002). Investigation of submarine groundwater discharge. Hydrological Processes, 16, 2115-2129.

Tcherepanov, E.N., Zlotnik, V.A., \& Henebry, G.M. (2005). Using Landsat thermal imagery and GIS for identification of groundwater discharge into shallow groundwater-dominated lakes. International Journal of Remote Sensing, 26, 3649-3661.

Tovar-Sanchez, A.A., Basterretxea, G., Rodellas, V., Sanchez-Quiles, D., Garcia-Orellana, J., Masque, P., ... Garcia-Solsona, E. (2014). Contribution of groundwater discharge to the coastal dissolved nutrients and trace metal concentrations in Majorca island: karstic vs detrital systems. Environmental Science E Technology, 48, 11819-11827.

Valle-Levinson, A., Marino-Tapia, I., Enriquez, C., \& Waterhouse, A.F. (2011). Tidal variability of salinity and velocity fields related to intense point-source submarine groundwater discharges into the coastal ocean. Limnology and Oceanography, 56, 1213-1224.

Wilson, J., \& Rocha, C. (2012). Regional scale assessment of submarine groundwater discharge in Ireland combining medium resolution satellite imagery and geochemical tracing techniques. Remote Sensing of Environment, 119, 21-34.

Xin, P., Robinson, C., Li, L., Barry, D., \& Bakhtyar, R. (2010). Effects of wave forcing on a subterranean estuary. Water Resources Research, 46.

Young, C., Tamborski, J., \& Bokuniewicz, H. (2015). Embayment scale assessment of submarine groundwater discharge nutrient loading and associated land use. Estuarine, Coastal and Shelf Science, 158, 20-30.

Young, C.R. (2013). Geosciences (pp. 165). Stony Brook University (PhD Dissertation) 